NBER WORKING PAPER SERIES

\title{
PENSION REFORM AND ECONOMIC PERFORMANCE IN BRITAIN IN THE 1980s AND 1990s
}

\author{
Richard Disney \\ Carl Emmerson \\ Sarah Smith \\ Working Paper 9556 \\ http://www.nber.org/papers/w9556 \\ NATIONAL BUREAU OF ECONOMIC RESEARCH \\ 1050 Massachusetts Avenue \\ Cambridge, MA 02138 \\ March 2003
}

We are grateful to participants at the pre-conference, the editors, and Alissa Goodman for comments on an earlier draft. Colleagues at the Institute for Fiscal Studies offered useful advice. The views expressed here are those of the authors and not their employers. Any errors are the responsibility of the authors alone. The background work was funded by the ESRC Centre for the Microeconomic Analysis of Fiscal Policy at IFS. The Family Resources Survey is Crown Copyright and the Data Archive is thanked for access to the British Household Panel Survey. The views expressed herein are those of the authors and not necessarily those of the National Bureau of Economic Research.

(C2003 by Richard Disney, Carl Emmerson, and Sarah Smith. All rights reserved. Short sections of text not to exceed two paragraphs, may be quoted without explicit permission provided that full credit including Cnotice, is given to the source. 
Pension Reform and Economic Performance in Britain in the 1980s and 1990s

Richard Disney, Carl Emmerson, and Sarah Smith

NBER Working Paper No. 9556

March 2003

JEL No. H2

\section{$\underline{\text { ABSTRACT }}$}

The late 1980s saw a major shift in pension provision in the United Kingdom, when for the first time individuals were permitted to opt out of part of the social security program into individual retirement saving accounts (Personal Pensions). At the same time, membership of company-provided pension plans (occupational schemes) was made voluntary. The paper explores the possible impact of these, and other related changes in social security in the 1980s and 1990s in the UK, on household saving rates, on current and future public finances, on retirement, and on the job mobility of individuals covered by company pension plans.

\section{Richard Disney}

School of Economics

University of Nottingham

University Park

Nottingham NG7 2RD UK

richard.disney@nottingham.ac.uk

Sarah Smith

The Financial Services Authority, 25 The North Colonnade, Canary Wharf, London E14 5HS UK sarah.smith@fsa.gov.uk

\section{Carl Emmerson}

Institute for Fiscal Studies

7 Ridgmount Street

London WC1E 7AE UK

carl.emmerson@ifs.org.uk 


\section{PENSION REFORM AND ECONOMIC PERFORMANCE IN THE UK IN THE 1980S AND 1990s ${ }^{1}$}

\section{Introduction}

\subsection{Overview of reform process}

Over the last fifteen years, successive United Kingdom governments have embarked on a series of reforms of the pension programme designed both to reduce the prospective costs of social security, and also to permit more flexibility and individual choice in secondary pension provision. ${ }^{2}$ Central to this strategy has been an evolution of the mechanism of 'contracting-out', introduced originally in 1978 as a means of integrating existing occupational pension schemes into the new State Earnings-Related Pension Scheme, SERPS. In essence, contracting-out means that employers and employees obtain part of their social security pension through a private pension fund instead of the state. In compensation for establishing a private arrangement, employers and employees pay a lower payroll tax rate (known as the National Insurance contribution). An important consequence arises because the social security programme is purely pay-as-you-go (PAYG) financed, whereas most pension schemes, at least in the private sector, are fully-funded. Thus greater contracting-out implies greater pre-funding of pension commitments.

Under the 1978 arrangements, individuals could only opt out of part of the social security pension, SERPS, if they worked for an employer who provided an approved defined benefit (DB) occupational pension scheme. The approved scheme guaranteed to pay the employee a pension approximately equal to what they would have received from the state, known as the Guaranteed Minimum Pension. ${ }^{3}$ In return,

\footnotetext{
${ }^{1}$ There are some important differences in nomenclature between the US and Europe. In Europe, the term 'pension' tends to refer to all pensions, whether provided publicly (by the state) or privately. 'Social security', the term used for state-provided pensions in the US, has a different connotation in Europe, generally referring to the whole social insurance scheme. 'Occupational pension' is a specific term in the UK referring to an employer-provided (group) pension scheme. Finally, the basic state retirement pension in the UK, which pays (broadly) the same weekly amount to all pensioners and pensioner couples, is often referred to as a 'flat rate' pension - although in the US, 'flat rate' is sometimes used as a term for a proportional tax system.

${ }^{2}$ The structure of the first tier of coverage (the basic state pension) was unchanged by these reforms, though its generosity was reduced. See Dilnot et al (1994), Disney, Emmerson and Tanner (1999) and Banks and Emmerson (2000).

${ }^{3}$ There were however some important differences - for example indexation post-retirement of the GMP was in part subsidised by the government, see Dilnot et al (1994) for further details.
} 
the employer would pay a lower combined rate of employee and employer National Insurance contributions to the government. ${ }^{4}$

However, a major innovation in pension policy occurred in 1988, as a result of the 1986 Social Security Act. The government was worried by the projected cost of SERPS once the baby boom generation began to retire in the first quarter of the twenty first century (Hemming and Kay, 1982; Department of Health and Social Security, 1984), and sought to cut projected public pension expenditure. To do this, it needed ways to encourage a greater number of individuals to contract-out of SERPS. The government adopted a 'stick' and 'carrot' strategy to this problem. The 'stick' was to reduce the generosity of SERPS considerably, so giving a greater incentive to opt out. But coverage by existing defined benefit (DB) occupational pensions was stagnating. Therefore a 'carrot' was needed. This took the form of giving individuals and employers new incentives to contract out, by permitting defined contribution pension plans also to opt out of SERPS, on what turned out be extremely favourable terms. ${ }^{5}$ The government perhaps expected this extra 'wave' of opting out to occur through employer-based defined contribution (DC) plans, but in fact the dominant new form of arrangement became the individually-purchased retirement saving account known as a personal pension. ${ }^{6}$

Contracting out works in a somewhat different manner in an individually purchased personal pension. Here the individual makes a contract with an approved private insurance company. The Department of Social Security (DSS) acts as the 'clearing house', so that the full National Insurance contribution is paid by the employer to the Inland Revenue, and the contracted-out rebate component is then

\footnotetext{
${ }^{4}$ The difference between the 'contracted in' and 'contracted out' National Insurance rates is known as the contracted out rebate. Note that, in the UK, most income tax and National Insurance contributions, whether notionally levied on the employee or employer, are collected at source from the employer by the Inland Revenue.

${ }^{5}$ See discussion below, and National Audit Office (1991). Of course employers offering DC plans could not guarantee a target benefit, so the employer was instead required to make a guaranteed minimum contribution in such schemes.

${ }^{6} \mathrm{DB}$ plans are plans that guarantee a nominal benefit, typically related to a measure of salary. DC plans simply promise to pay an (unknown) annuity based on the accumulated fund of contributions plus investment returns. A reason for the popularity of personal pensions was that they were heavily advertised and sold. They offered greater flexibility and very generous tax reliefs, but a contributing factor arose because the government had just eliminated tax relief on life insurance. Many insurance companies therefore switched their salesforces to the pension market, and this decision contributed a good deal to the subsequent controversy concerning the 'mis-selling' of personal pensions.
} 
transferred and paid directly by the DSS to the individual's approved personal pension provider. $^{7}$

Personal pensions were also encouraged by the fact that the 1988 legislation made membership of a pension scheme, whether state-provided or employerprovided, entirely a matter of choice: that is, an individual had to belong to an approved contracted out scheme or SERPS, but could not be forced by their employer to join a company scheme. ${ }^{8}$ Roughly $25 \%$ of the workforce (over 6 million employees) opted to purchase personal pensions over the period 1988-92, including some one million who opted to leave or not to join an existing employer's pension plan. By the middle of the 1990s, roughly three quarters of the workforce had contracted-out of SERPS into some form of private plan, whether DB or DC, or employer-provided or individually purchased. ${ }^{9}$

It should be noted, finally, that individuals are also free to switch in their working life between different types of pension plans. Crucially, and unlike some other countries that have gone down this road, contracting out of the social security programme need not be permanent. ${ }^{10}$ Indeed, between 1988 and 1995, there were incentives for individuals who contracted out of SERPS to contract back in to the social security programme at a later age (Disney and Whitehouse, 1992a).

These reforms, augmented by further substantial measures in 1995, are far from the end of the pension reform programme in the UK. Indeed in 1998 and 1999 the new Labour government proposed a number of further reforms, including yet another 'route' for contracted out private provision (alongside occupational and personal pensions) known as ‘stakeholder pensions' (Department of Social Security, 1998). These will basically be benchmarked personal pensions, which all employers employing 5 or more people will be required to make available to their employees at

\footnotetext{
${ }^{7}$ Thus the contracted out rebate can be varied across individuals, which is not possible in a group scheme where the same percentage rebate is paid for all scheme members.

${ }^{8}$ At the same time, an employer could not refuse to let an employee join a scheme on the grounds of, say, being part-time as this constituted a form of indirect discrimination (against women). For the same reason, differential vesting on grounds of gender is not permitted, and indeed vesting periods in employer-provided plans are not a big issue in the UK, being very much shorter than, say, the US.

${ }^{9}$ Somewhat surprisingly, it is impossible to find any official data that provides the proportions of workers contracted in or contracted out to different types of pension plans, over time.

${ }^{10}$ For an analysis of opting out arrangements in a number of countries, see Disney, Palacios and Whitehouse (1999).
} 
the workplace (although they will not be directly provided by employers). The idea of this reform is to provide a low cost pension for those not covered by traditional employer plans, thereby reducing administrative charges relative to individual plans and making pension arrangements more transparent. While this in some ways a positive step, given some of the difficulties with the other pension 'routes', there must be some concern as to whether further augmenting choice of individual pension arrangement assists in clarifying or simplifying the UK pension system. At the same time, over a long transition period, SERPS will be replaced by a more explicitly redistributive public pension benefit known as the State Second Pension (or, in some quarters, as $\mathrm{S} 2 \mathrm{P}){ }^{11}$

The main thrust of this paper, however, is not to go through the intricacies of the UK pension reform process in the 1980s and 1990s, which would require a whole volume. We do indeed sketch out the UK pension scheme in Section 2, mentioning some other important facets to the reform process, such as cutbacks in the flat basic state pension, and greater targeting on poor pensioners. The primary purpose, however, is to ask what impact these reforms might have on the UK's economy. ${ }^{12}$ The shift to a greater share of private pension provision, and to greater choice of pension provision, reflect the central tenets of the Conservative administrations of the 1980s and the first half of the 1990s. However, the Labour administration that came to power in 1997 showed no inclination to reverse this process of opting out of state provision, preferring instead further to focus public resources available on poorer pensioners by increasing the generosity of the main means-tested benefit, through the Minimum Income Guarantee. While 60 per cent of pensioner income is currently provided by the state the current government has stated that it expects this to fall to 40 per cent by the middle of this century (Department of Social Security, 1998).

\subsection{Pension reform in the UK: The issues and summary of our main findings}

This chapter therefore examines some of the implications of the sequence of pension reforms for the UK economy. Given space constraints, we focus on impacts on the real economy, leaving aside developments in the financial economy, such as

\footnotetext{
${ }^{11}$ For further discussion of all these issues, see Disney, Emmerson and Tanner (1999).

${ }^{12}$ For some interesting details on the political process, see Lawson (1992) and Peacock (1992).
} 
the consequences of greater private pension provision for the UK's capital market. In particular, we examine five aspects of the economy where pension schemes, and pension reform, might be expected to have some effects. These areas, with a summary of the main findings are:

- Pension reform affects macroeconomic performance through its impact on household savings rates. Contributions to occupational pension funds have significantly contributed to household saving for many years in the UK. The introduction of personal pensions in 1988 had both a positive substitution effect increasing household saving rates and also a positive effect on wealth which will have reduced household saving rates. Our tentative conclusion is that personal pensions contributed a negligible net amount to household saving at the end of the 1980s, despite massive take-up. But a decade later, due to the fact that contributions direct from individuals and their employers had become more important than those from the DSS paid contracted-out rebate, personal pensions are likely to have contributed more substantially to household saving.

- The public finances, and especially the government's intertemporal budget constraint are affected by pension reform. Permitting individuals to opt out of part of the state pension programme has both intertemporal effects (current versus future tax rates) and intragenerational effects (the relative tax rates paid by opted (contracted) out and contracted in individuals). These effects arise from the PAYG nature of the financing of the state pension scheme. Our conclusion is that the contracting out arrangements have raised payroll tax rates by around $2 \frac{1}{2} 2$ to 3 percentage points, relative to the status quo. It will reduce payroll tax rates by somewhat less as opted out pensioners retire later in this century. Note that it is inherent in rational voluntary switching that the government never recoups fully its initial payroll tax reductions designed to encourage opting out.

- The impact on the distribution of incomes. Ideally, we need a lifetime perspective to trace the impact of greater contracting out on lifetime incomes. In static comparisons, for example of pensioner inequality, we might expect greater contracting out to lead to greater inequality for two reasons. First, private pension incomes may be more volatile. Second, in the 1980s and 1990s, average private pensions grew much faster than the contracting-out arrangements had assumed. This made them worth more than state pensions and better off earners tend to contract out. 
The future impact of personal pensions on income inequality will depend not just on future investment returns but also on the retirement behaviour of optants.

- Labour supply (and especially retirement behaviour). Different types of pension schemes have different effects on retirement behaviour. There has been a trend to earlier retirement, especially among men, in the UK in the 1980s and 1990s. This has been encouraged by the use of existing occupational pension schemes and by the relative generosity of the public disability system - since somewhat reduced (Blundell and Johnson, 1999; Disney, 1999). The majority of optants to personal pensions are somewhat younger than the average workforce and the effect on retirement behaviour cannot yet be seen. It is clear that defined benefit schemes will discourage early retirement relative to defined contribution schemes, due to the fact that the former are back-loaded while the latter are front-loaded (Blundell, Meghir and Smith, 2001). However contracting out of state pensions into a personal pension has both a wealth effect and a substitution effect which work in opposite directions for the labour supply of older workers. The net impact on labour supply could go either way.

- The general operation of the labour market - in particular, how pension reforms might have affected labour market 'flexibility'. Here we focus on job mobility and take-up of personal pensions, the hypothesis being that individualised personal pensions encourage more mobility, or at least, are taken up by more mobile workers. Given the inherent simultaneity of this issue, it is hard to identify causation. Nevertheless the introduction of personal pensions offers an unusual 'natural experiment', arising from the ability of individuals to choose a personal pension in preference to a company pension plan, if offered. We show that individuals that chose to opt out of a company pension plan did indeed exhibit significantly higher subsequent job mobility. In principle further analysis of this experiment will offer a more precise 'test' than the existing (largely inconclusive) literature on pension scheme tenure and job mobility.

\section{Overview of reforms in the UK}

\subsection{Broad framework of UK pension provision}

The section briefly outlines the current UK pension system, and the reforms made over the last twenty years. A more detailed description can be found in, among 
others, Budd and Campbell (1998); Dilnot, Disney, Johnson and Whitehouse (1994); Banks and Emmerson (2000), and Emmerson and Johnson (2001). Figure 2.1 provides a diagrammatic representation of the current UK pension system.

The UK pension system is split into three tiers. The first is provided by the state, and consists of the basic state pension and a significant means-tested (noncontributory) benefits sector. The basic state pension is a flat contributory benefit which is financed on a pay-as-you-go basis. The basic state pension in 2001-02 will be worth $£ 72.50$ a week for a single pensioner ${ }^{13}$, which is about fifteen per cent of average male earnings. This is down from around twenty per cent of average earnings in the early 1980s which is as a result of the basic state pension having been increased broadly in line with price inflation since 1981 while average earnings have grown in real terms.

Figure 2.1

Schema of UK pension scheme, 2001

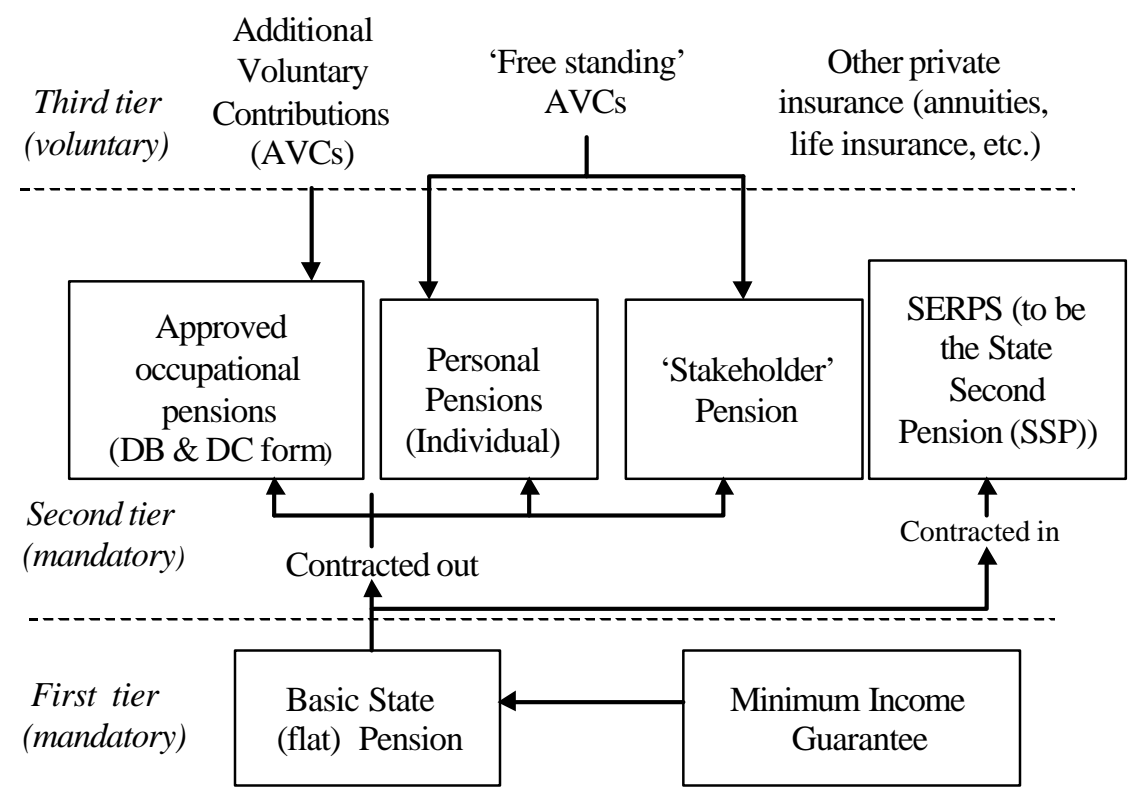

Source: Disney, Emmerson and Tanner (1999).

\footnotetext{
${ }^{13}$ Couples will receive $£ 115.90$. Source: HM Treasury (2000a).
} 
Those on low-incomes are eligible for the Minimum Income Guarantee (MIG) which in 2001-02 will be worth $£ 92.15$ a week for a single pensioner, nearly $£ 20$ more than the basic state pension. ${ }^{14}$ In addition pensioners on low-incomes may be eligible for housing benefit and council tax benefit, which are means-tested benefits designed to provide assistance towards housing costs and local taxes respectively. In 1998-99 some 21 per cent of pensioner couples and 47 per cent of single pensioners were in receipt of means-tested benefits. ${ }^{15}$ Government policy is, in the medium term at least, to continue increasing the basic state pension in line with prices while increasing the MIG in line with average earnings. Since the MIG is withdrawn at a rate of 100 per cent those with small amounts of income are left no better off than those with small amounts of income from savings. In response the government has proposed the introduction of a new 'pension credit' from April 2003 which will also be targeted at those with relatively low incomes. ${ }^{16}$

The social security system is financed on a Pay-as-You-Go (PAYG) basis. There is no equivalent of the US social security Trust Fund, although the National Insurance Fund has accrued surpluses over recent years (House of Commons, 2000). There are no plans to pre-fund social security, other than through the indirect route of contracting-out. The basic state pension and SERPS are financed from an earmarked payroll tax, the National Insurance contribution, notionally levied on employees up to an earnings ceiling and on employers with no earnings ceiling. Income-tested benefits are funded out of general taxation.

As described in the introduction, the second tier of mandatory pension provision is split between both state provision in the form of the State EarningsRelated Pension Scheme (SERPS) and private pension provision in the form of occupational pensions and personal pensions. The original SERPS scheme was introduced in 1978. This paid an individual one quarter of their earnings between a lower and an upper limit from the best twenty years of their lifetime. Earnings were to be uprated to retirement age by growth in average earnings, with payments in retirement then being indexed to prices. The Social Security Act of 1986 reduced the

\footnotetext{
${ }^{14}$ Source: HM Treasury (2000a).

${ }^{15}$ Source: Department of Social Security (2000a).

${ }^{16}$ For more information see Department of Social Security (2000b) and Clark (2001).
} 
generosity of SERPS by lowering the payments to twenty per cent of an individuals average earnings, with the average now to be calculated over their entire lifetime, rather than their best twenty years. ${ }^{17}$

Individuals were able to contract out of SERPS into an employers occupational pension scheme as long as it guaranteed a retirement income at least as high as SERPS - hence these schemes had to operate on a defined benefit basis. In return for 'opting-out', both they and their employer paid a lower rate of National Insurance Contribution. The 1986 Social Security Act took the principle of 'optingout' further by allowing individuals to choose to contract out of SERPS into a defined contribution pension scheme. In return for 'opting out' of SERPS in this way the government paid part of an individual's National Insurance Contribution into their pension fund. Since this payment was relatively generous this led to an enormous growth in personal pension take-up. More controversially the 1986 Social Security Act also allowed individuals the right to 'opt out' of an occupational pension scheme and into a personal pension scheme. This underlay the 'mis-selling' scandal of the late 1980s / early 1990s. This involved cases of people who were badly advised to take out personal pensions when they would have been better off staying in - or joining - their employers' occupational pension scheme. A large number of people were affected. By August 1999, some 400,000 people had been offered more than $£ 2.6$ billion compensation for having been mis-sold a personal pension. ${ }^{18}$

Further reform is also underway. SERPS is set to be replaced by the State Second Pension - which will be a flat rate top up to the basic state pension and hence more redistributive towards lower earners. ${ }^{19}$ In addition the government is introducing a 'stakeholder pension' which is essentially a personal pension with a heavily regulated charging structure, including an overall cap on charges. All employers will have to designate a scheme to their employees and allow individuals to make

\footnotetext{
${ }^{17}$ For more details see, for example, Emmerson and Johnson (2001). The original SERPS scheme could also be inherited in full by a surviving spouse. The 1986 Social Security Act reduced this to 50 per cent for those widowed after April 2000. However this change is now being phased in over a longer period as a result of government documentation failing to inform individuals of this change. See National Audit Office (2000) for more details.

${ }^{18}$ See Financial Services Authority (2000) for more details.

${ }^{19}$ Under current policies while the State Second Pension will be a flat rate pension the rebates paid to those opting out of this scheme will remain related to earnings. This will provide greater incentives for lower earners to stay in, or return to, the state scheme and for middle and higher earners to opt out of the state scheme. In future the rebate structure could be changed to mitigate these effects.
} 
contributions direct from their wages. They will not, however, have to make any contribution on their employees' behalf. ${ }^{20}$

Finally, there is a third tier of voluntary private retirement saving. This can involve making additional contributions into occupational pension plans (AVCs), additional saving through personal pensions, or in close substitutes among other financial assets (see Emmerson and Tanner, 2000).

\subsection{Demographic trends and projections of pension costs}

As in most developed countries, the ratio of those over pension age to those in work is set to rise in the UK over the next 30 years. However, ageing of the population is set to be less severe than in many OECD countries (Bos, Vu, Massiah and Bulatao, 1994). Moreover, due to the reforms made to the UK pension system over the last 20 years, the cost of the current system is not projected to require higher rates of National Insurance, as shown in table 2.1. This is a result of reforms such as the change to price indexation of the basic state pension in 1981, the substantial reduction in SERPS generosity in the Social Security Acts 1986 and 1995 and the increase in the state retirement age for women from 60 to 65 which is being phased in by 2020 . The reforms to SERPS reduce expenditure on SERPS in 2030-31 to around just 30 per cent of the level implied by the original scheme (Banks and Emmerson, 2000). While the replacement of SERPS with the State Second Pension will lead to an increase in state expenditure, the required National Insurance Contribution rate is still projected to fall by 2030 .

\footnotetext{
${ }^{20}$ For a more detailed description of the government's proposed pension reforms see, for example, Disney, Emmerson and Tanner (1999), Emmerson and Tanner (1999) and Agulnik, Barr, Falkingham and Rake (1999).
} 
Table 2.1. Long-term projections for the National Insurance fund (July 1999).

\begin{tabular}{|c|c|c|c|c|c|}
\hline & $2000-01$ & $2010-11$ & $2020-21$ & $2030-31$ & $2050-51$ \\
\hline Demographic forecasts (millions) & & & & & \\
\hline Contributors & 20.2 & 21.6 & 22.2 & 21.5 & 21.3 \\
\hline Pensioners & 11.0 & 12.3 & 12.6 & 15.2 & 15.8 \\
\hline Support Ratio & 1.8 & 1.7 & 1.8 & 1.4 & 1.4 \\
\hline State expenditures ( $£ b n, 1999-00$ prices $)$ & & & & & \\
\hline Basic State Pension & 34.4 & 38.0 & 41.3 & 49.4 & 51.2 \\
\hline SERPS & 5.2 & 9.9 & 12.6 & 14.9 & 15.8 \\
\hline Total Expenditure ${ }^{\mathrm{a}}$ & 48.6 & 57.7 & 65.9 & 76.2 & 79.0 \\
\hline Total Expenditure as a share of GDP (\%) & 5.4 & 5.6 & 5.5 & 5.5 & 4.2 \\
\hline $\begin{array}{l}\text { Joint employee and employer } \\
\text { contribution rates }^{\mathrm{b}}\end{array}$ & 19.9 & 18.9 & 18.1 & 18.6 & 15.2 \\
\hline $\begin{array}{l}\text { GDP per pensioner spending, } \\
(1999-2000=100)\end{array}$ & 99.5 & 93.0 & 87.8 & 75.4 & 56.2 \\
\hline
\end{tabular}

\subsection{The 'pension burden': comparison with other countries}

The reforms to the UK pension system have ensured that future liabilities will, at the very least, not require substantial rises in tax rates. This is in contrast with many other developed countries, as shown in table 2.2. The UK is the only country in which state pension expenditures are forecast to fall. The table also shows that only the United States, of the countries considered, spends a smaller proportion of GDP on public pension benefits. 
Table 2.2. Projected future state spending on pensions as a percentage of GDP

\begin{tabular}{l|ccccccc}
\hline \hline & 2000 & 2010 & 2020 & 2030 & 2040 & 2050 & $\begin{array}{c}\text { Net liability, } \\
1995-2050 \mathrm{a}\end{array}$ \\
\hline Canada & 5.0 & 5.3 & 6.9 & 9.0 & 9.1 & 8.7 & 67.8 \\
France & 9.8 & 9.7 & 11.6 & 13.5 & 14.3 & 14.4 & 113.6 \\
Germany & 11.5 & 11.8 & 12.3 & 16.5 & 18.4 & 17.5 & 110.7 \\
Italy & 12.6 & 13.2 & 15.3 & 20.3 & 21.4 & 20.3 & 75.5 \\
Japan & 7.5 & 9.6 & 12.4 & 13.4 & 14.9 & 16.5 & 106.8 \\
New Zealand & 4.8 & 5.2 & 6.7 & 8.3 & 9.4 & 9.8 & 20.4 \\
UK & 4.5 & 5.2 & 5.1 & 5.5 & 4.0 & 4.1 & 4.6 \\
US & 4.2 & 4.5 & 5.2 & 6.6 & 7.1 & 7.0 & 25.7 \\
\hline
\end{tabular}

aThe sum of projected future deficits, each expressed as percentage of projected future GDP.

Sarces Roseveare, Leibfritz, Fore and Wurzel (1996); Chand and Jaeger (1996) for net pension liabilities.

While these reforms have led the UK pension system to sustainability in terms of costs it remains to be seen whether it is sustainable in terms of fairness, with the proportion of national income given in public pensions to each pensioner falling to 75 per cent of the current level by 2030 and 56 per cent by 2050 . It should also be remembered that these costings do not include the cost of means-tested benefits to pensioners, which in 1998-99 was some 1.0 per cent of GDP (Banks and Emmerson, 2000). The governments long term aim to increase the Minimum Income Guarantee in line with average earnings, and the introduction of the pension credit in April 2003 will add to these future liabilities. Also previous forecasts of demographics have tended to underestimate improvements in longevity and hence underestimate liabilities (Disney, 2000).

\subsection{Economics of the choice of private pension provider}

The decision to opt out of the social security scheme involves assessing the present value of the alternatives (Disney and Whitehouse, 1992a,b, Disney, Palacios and Whitehouse, 1999). For an individual offered the chance of joining an occupational pension scheme, the decision will depend on the likely time path of salary and, more crucially, expected job tenure. For an individual choosing between a personal pension and some form of defined benefit plan - whether publicly or employer-provided, age is a key determinant. Simply put, contributions put into a defined contribution plan such as a personal pension earlier in the working life compound over a longer period, while the fund will cumulate over both negative and positive investment shocks the longer the period to retirement.

In contrast, in any defined benefit scheme where there are penalties to early leaving and where pension benefit are in some way related to final salary, later 
contributions 'earn' a greater prospective pension (for illustrations, see Bodie et al, 1988, and, in the UK context, Disney and Whitehouse, 1996). Consequently we should expect to see optants for personal pensions to be relatively young, in contrast to, say, the age structure of purchasers of Individual Retirement Accounts in the United States, where there is no similar choice-based structure of second tier pension provision.

This finding is confirmed in figure 2.2: the median age of personal pension optants is the early thirties. This is important if we are to understand where personal pensions might have had an impact (for example on job mobility) and where they might not (for example, on observed retirement behaviour).

Figure 2.2. Personal pension coverage, by age, gender and employment status, 1998.

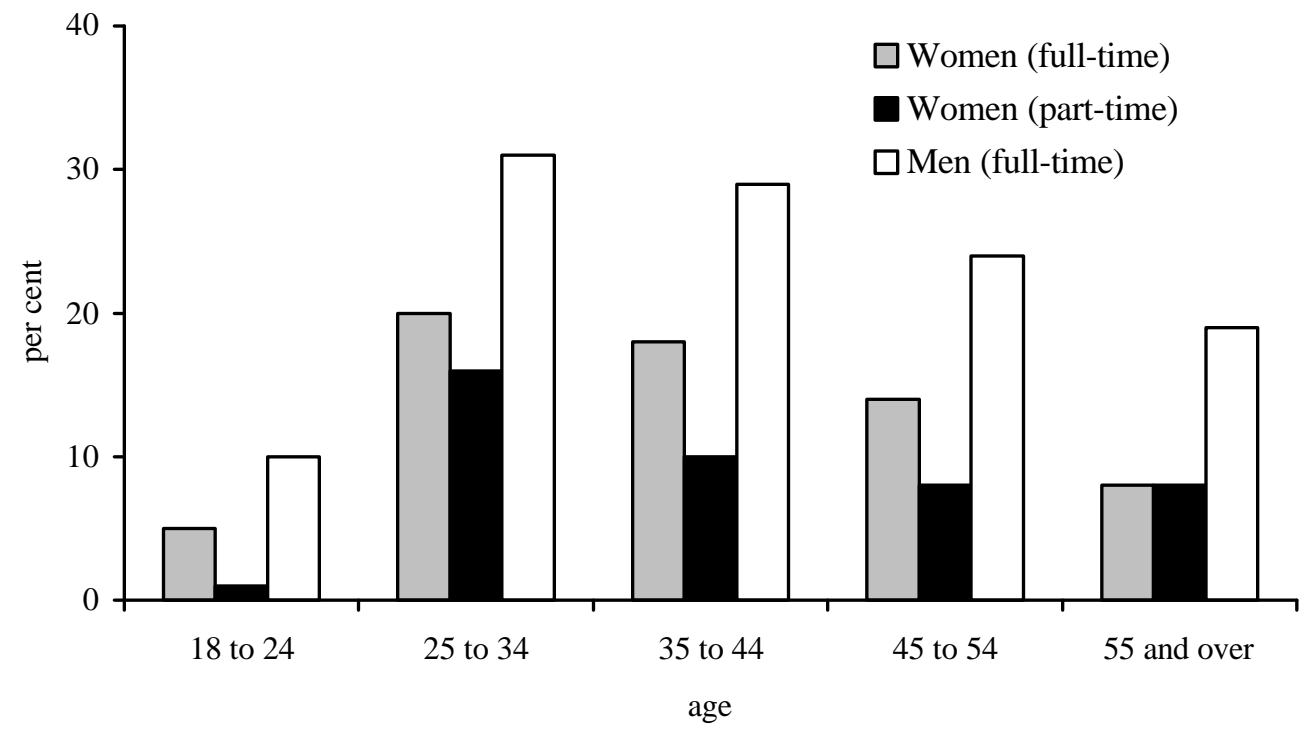

Note: Employees in Great Britain aged 18 and over, excluding those in youth training and employment training. Part-time male employees not shown due to small sample sizes.

Source: Office for National Statistics (2000).

Private pension coverage also varies by earnings. Those in more highly paid jobs are more likely to be members of an occupational pension scheme. As shown in figure 2.3, coverage of personal pensions is distributed more widely across the earnings distribution. Only among those not in paid employment and those in the 
lowest ten percent of the earnings distribution does personal pension coverage fall below twenty per cent. ${ }^{21}$

Figure 2.3. Private pension coverage, by earnings decile, 1992

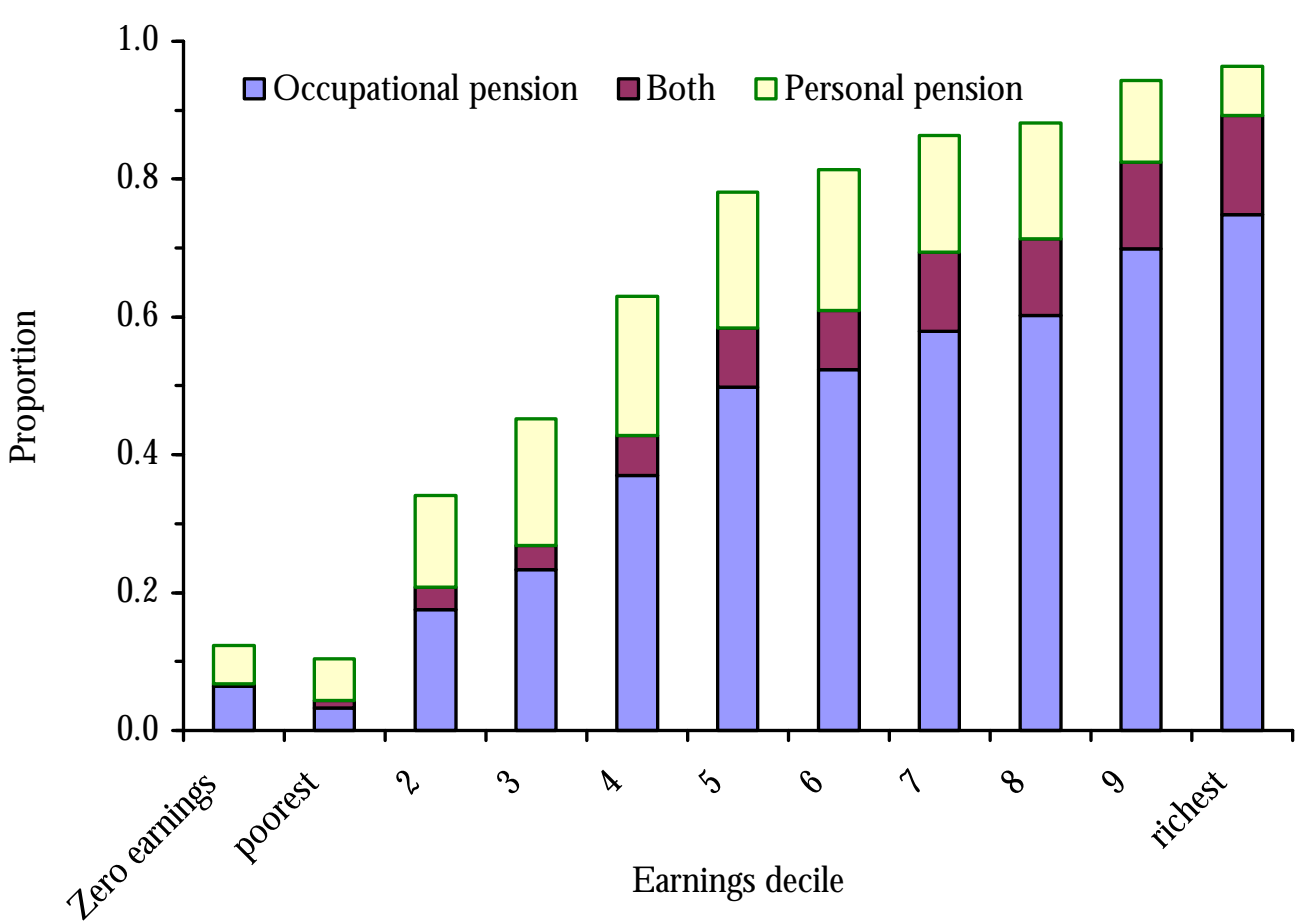

Note: Includes only individuals aged 20 to 59 in 1991 who are present in the first eight waves of the BHPS. Those reporting to be self-employed in any of waves 1 to 8 have been excluded from the analysis.

Source: Adapted from Disney, Emmerson and Wakefield (2001), using data from the British Household Panel Survey.

\section{Pension reform and macroeconomic performance}

\subsection{Impact on saving of the demographic transition and pension reform}

At the macroeconomic level, the simplest view of contracting out sees it as shifting pension provision from a tax-financed basis to one in which pensions are increasingly funded through private saving. With greater inducements to contract out, as were put in place in the late 1980s, measured personal saving rates should therefore

21 Before April 2001, people with no earnings couldn't contribute to a personal pension since contributions were earnings related. The fact that personal pension coverage among non-earners is nonzero reflects the fact that the question on personal pensions asks about the previous twelve months. From April 2001 the annual contribution limit is a flat $£ 3,600$ per year or an earnings-related amount, whichever is greater. This means that non-earners will be able to contribute to a personal (or stakeholder) pension for the first time. There is also no age limit, so some babies will find themselves with a pension taken out on their behalf. 
rise simply because of the way that national accounts data treat individual saving relative to payroll tax contributions. Leaving aside accounting conventions, however, it is still generally accepted in the literature that the national saving rate and capital stock will be higher in an economy where pension provision is funded rather than tax financed, although the rate of return on capital will be lower. ${ }^{22}$ Whether, in turn, an economy with a funded pension scheme grows faster depends on the exact growth mechanism postulated - in the basic Swan-Solow model, for example, the long run growth rate is independent of the saving rate, whereas in many endogenous growth 'stories', the growth rate depends positively on the saving rate.

This speculation on the likely behaviour of household saving rates should also take account of the demographic transition. The future UK economy will be one with a lower support ratio of those of working age to pensioners (see 2.2 above) - indeed this was one motivation for the shift to funded provision. What is the effect on saving of this declining support ratio? On the one hand, if individuals live longer with a constant retirement age and a continued replenishment of the labour force (as seems to be the UK scenario), a simple life cycle hypothesis ( $\mathrm{LCH}$ ) model would suggest that the average saving rate should be higher (Modigliani, 1986). On the other hand, if the size of the workforce is actually declining, capital requirements are less and the saving rate need no longer be so high to maintain the workforce's capital stock (Cutler et al, 1990). Hence we also need to take account of the fact that the baby boom generation is currently middle-aged, and, in a standard LCH model of saving, are strong net savers. As they retire, however, they should become net dissavers, even if the way that savings rates are measured often conceals this fact (Miles, 1999). On balance, therefore, this combination of demographic trends and pension reform suggests that the underlying saving rate in the UK economy should be increasing.

Figure 3.1 charts the annual average household saving rate against net accumulation in private pension schemes over the period $1970-96 .{ }^{23}$ This latter series, which is the difference between inflows of accumulated contributions and investment

\footnotetext{
22 This is in general the case so long as Ricardian equivalence does not hold - that is, individuals do not adjust their saving behaviour fully to offset changes in future tax liabilities, and abstracting from international capital flows.

${ }^{23}$ As a result of the UK introducing the European System of Accounts 1995 the methodology for calculating the savings rate has changed and it is no longer possible to get a consistent series for saving in private pensions. Between 1996 and 2000 the savings rate fell sharply. For more details see Disney, Emmerson and Wakefield (2001).
} 
returns, and outflows of pension lump sums and disbursements of annuities, is much more stable than the household saving rate, which exhibits some countercyclical volatility. Since aggregate household saving rates are net flows, typically calculated as residuals, it is hard exactly to measure the contribution of pension contributions in total saving. Disney (1997) suggests that of around $£ 65$ billion net saving in non-fixed assets in the UK in 1996, roughly $£ 21$ billion was through employer-provided pension plans and $£ 3.7$ billion through personal pensions.

There is no obvious trend in retirement saving despite the introduction of new retirement saving instruments, notably personal pensions. But as can be seen from the cited statistics, saving in personal pensions is still relatively low. An important related issue, however, is how much saving through personal pensions is net new saving, rather than just saving that would have been held in other forms? To examine this, we have to consider some further extensions of our model. Implicit in our stylised discussion is a LCH model of a representative individual, with identical rates of return between all forms of pension 'saving', no precautionary saving, and no differences in the risk attached to contributions to the social security programme and to private pension schemes. The pension reform process in the UK does not warrant such assumptions, and some further analysis is required.

Figure 3.1:

Savings rate and rate of saving in funded pensions, 1970 to 1996.

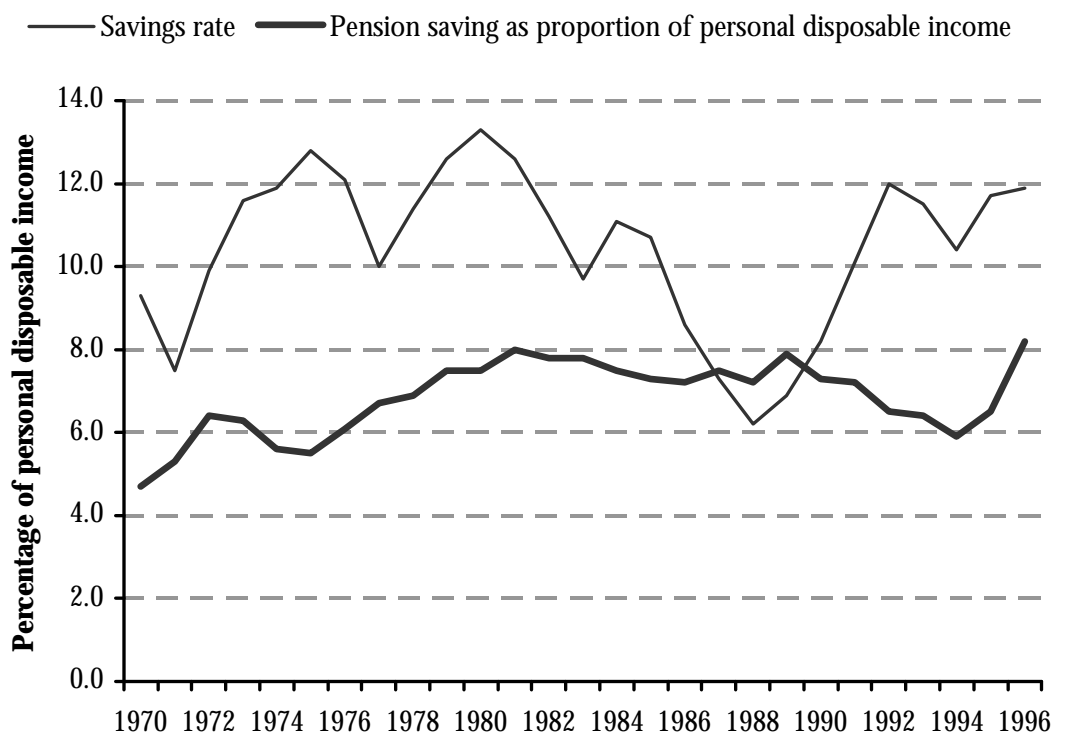

Note: Uses figures calculated before ESA standards had been introduced.

Source: ONS: The Blue Book. 


\subsubsection{Differential rates of return}

When considering whether the introduction of personal pensions would be expected to have led to an increase in saving it is important to consider both wealth and substitution effects arising from the policy change. A basic issue is whether 'saving' in the form of contributions to a private pension plan rather than through the social security system has a zero impact on private sector wealth, when discounted at the risk adjusted rate of return (Engen and Gale, 1997). The answer depends on the implicit internal rate of return on social security contributions relative to the return on saving in a private pension scheme. It also depends on the return on savings in new pension instruments (such as personal pensions) relative to the return on similar financial assets (if any) that were previously available. If the discounted return on net social security wealth is negative (as has clearly been the case in the UK) ${ }^{24}$, then permitting individuals to 'invest' part of their National Insurance contribution in a contracted out scheme generates a positive retirement wealth effect. This might induce an increase in consumption and therefore a reduction in other personal saving. On the other hand, to the extent that personal pensions, for example, are 'new' assets , for example if they are able to offer higher returns (at least, in their tax relieved treatment), the reforms may have created new saving and as well as diverting saving.

There are two types of contributions to personal pensions. First, there are payments of contracted-out rebates (CORs) via the Department of Social Security (DSS). Assuming these would otherwise have been contributed to the social security programme (SERPS) and earned low returns, these transfers induce a positive lifetime wealth effect that should increase consumption and reduce other saving. On the other hand, payments of discretionary contributions into plans, on top of CORs, should represent some new net saving, depending on how substitutable personal pensions are with existing financial assets that are not retirement saving vehicles.

Figure 3.2 charts both payments of contracted-out rebates by DSS into personal pension accounts and discretionary contributions by employees and by employers on their behalf over the period 1988-89 to 1998-99. Note the reversal of the relative magnitude of these inflows over the period, largely arising from effective

\footnotetext{
${ }^{24}$ Disney and Whitehouse, 1993a,b, found negative returns on social security contributions for men born after 1955 even before the cutbacks in provision in the 1990s.
} 
cutbacks in the value of CORs in the 1995 Act. Given the wealth and substitution effects, one might reasonably conclude that there was little or no net saving through personal pensions at the start of the period but a more significant amount by the late 1990s. ${ }^{25}$

Figure 3.2:

\section{Contributions to personal pensions, by type of contribution (1998-99 prices)}

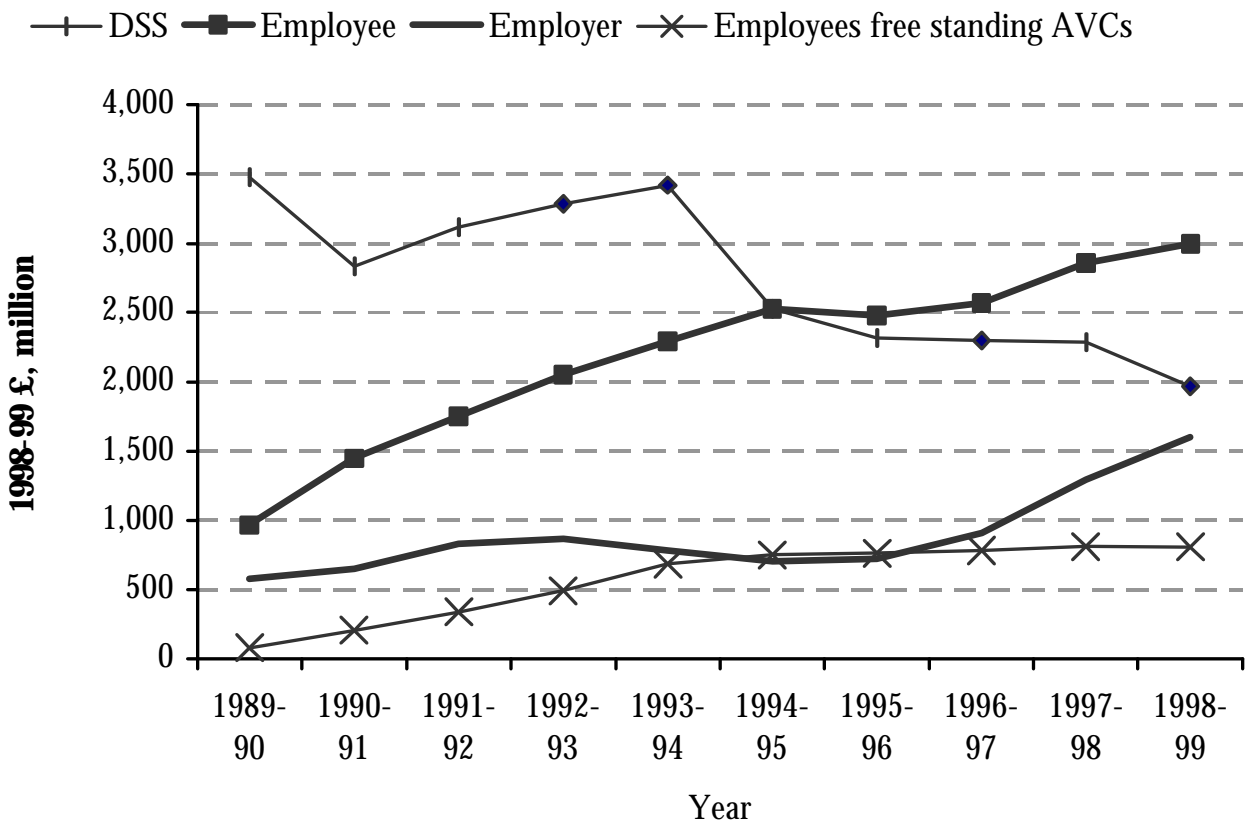

Source: HMSO Inland Revenue Statistics, (tables 7.1 and 7.2), deflated by authors.

\subsubsection{Pension reform, income distribution and saving}

Section 4 focuses on the distributional impact of the pension reforms. Nevertheless some preliminary remarks are useful in the context of saving. First, social security provision is likely to be more redistributive than private provision.

\footnotetext{
${ }^{25}$ Disney et al (2001) use the following benchmarks. Suppose the marginal propensity to consume out of wealth is 0.07 and $70 \%$ of payment of CORs into personal pensions are treated as 'new' pension wealth by households. Then other saving will be reduced by $4.9 \%$ of contracted-out rebates paid into personal pensions - this is a pure wealth effect. The net saving effect is the total amount paid in discretionary contributions into personal pensions, less the 'offset' impact on other saving and the tax subsidy. Assume this offset coefficient rose from 0.3 to 0.4 over the period as closer substitutes became available, and that the tax relief on discretionary contributions averaged 0.23 . These figures are comparable with averages from other studies of saving effects, as discussed in that paper. Then simple arithmetic suggests that personal pensions contributed less than an additional $£ 0.5$ billion to household saving in $1988-89$ but close to $£ 2$ billion in $1998-99$. The latter is around $0.2 \%$ of GDP.
} 
This factor is likely to be enhanced where contracting out is voluntary, which permits richer households to opt out of redistribution. The fact that the majority of the workforce have contracted out of SERPS limits the potential for redistribution in both political and economic terms.

At first sight, a redistribution from high to low income households should reduce aggregate saving when saving is disproportionately carried out by richer households. ${ }^{26}$ But, as Gale (1998) points out, the ultimate outcome may be reduced if low and high income households have differing substitution elasticities between social security, private pensions and other assets. High income households may alter their saving patterns (for example, changing their asset portfolio) to offset the redistributive impact of social security, while, if low households do not save at all, the degree of redistribution has little impact on those households' behaviour.

In addition, the redistribution inherent in pension schemes is more complex than simply from 'rich' to 'poor' people. In the first place, we have to look at lifetime incomes, and take differential longevity into account. Secondly there are also issues to do with gender, such as how spouses are treated (Disney and Johnson, 2001, Introduction). In fact the UK social security pension scheme, pre-reform, was not particularly redistributive in terms of lifetime incomes across the male income distribution (Creedy, Disney and Whitehouse, 1993). The main beneficiaries of redistribution were women, who reached state pension age earlier (60 rather than 65), lived longer, and disproportionately benefited from spouses' benefits. So how reform affects household saving rates is unclear a priori, depending on, for example, whether couples take account of each other's survival probabilities (or any other joint aspects for that matter) in their individual saving decisions.

\subsubsection{Risks attached to alternative pensions}

A standard argument is that DB schemes involve risk-sharing, whether between generations and individuals (in a public scheme), or between employers and employees (in occupational pension schemes). If individual employees are risk averse, then contracting out into a DC scheme (such as a personal pension) changes the risk environment facing individuals (Bohn, 1997) and should affect the amount of precautionary saving. Of course, social security is not devoid of risk (political risk)

\footnotetext{
${ }^{26}$ For empirical evidence for the UK, see Banks and Tanner (1999).
} 
for example the substantial reductions in the generosity of state pensions in the UK that have occurred over the last twenty years. It is also true that occupational pension plans have not always been divorced from individual risk in the UK, as the Maxwell scandal indicated. ${ }^{27}$ Nevertheless, this issue is an important one in a mandatory transition strategy, particularly where individuals perceive the change as implying a change in the risk environment. However, the voluntary nature of contracting out in the UK presumably permits those with different risk-return trade-offs to choose alternative strategies. The issue therefore is one of whether people fully understand the risks involved in alternative pension choices in the UK (Banks and Emmerson, 2000). But, whether they understand them or not, this risk issue should not affect the saving rate a good deal. ${ }^{28}$

\subsection{The public finances and the 'transition burden'}

Our analysis of saving behaviour examines the implications of the shift from tax-financed social security to funded provision. But this transition comes at a price; a price which has been a pertinent consideration for the UK economy in the past two decades, and for the foreseeable future. A consequence of a transition towards a larger funded component of the pension programme is a higher current average payroll tax rate than would otherwise be the case. Current social security liabilities have to be financed from a smaller tax base, given that contracting out reduces tax receipts from National Insurance contributions.

Table 3.1 provides some official evidence on the impact on contracting-out on the average payroll tax burden. It shows that National Insurance contribution rates are some $2 \frac{1}{2}$ to 3 percentage points higher than they would otherwise be as a result of contracting-out, with around 1 percentage point arising from the introduction of

\footnotetext{
${ }^{27}$ There is no equivalent of the pension fund guarantee that exists in the US to provide some insurance across plans. Instead, occupational pension funds are required to satisfy certain investment requirements that are monitored by the plan trustees. It is these arrangements that broke down in the Maxwell case when auditors discovered that the pension funds of the Robert Maxwell Group had been lent, with no collateral, to private companies within the group, leaving no funds available to satisfy the pension liabilities. For a lucid description of this event, and the aftermath, see Blake (1995). The 1995 legislation has tightened up the supervisory mechanisms. Bear in mind also that the component of the pension benefit that is supposed to substitute for the state benefit, SERPS, was guaranteed.

${ }^{28}$ In other words, if individuals choose personal pensions because they are less risk averse, they should not engage in (greater) precautionary saving. If they do not perceive the potential change in their risk environment, it should not affect their other saving either.
} 
personal pensions alone. Note from Figure 3.2 that this percentage attributable to personal pensions was even higher in the late 1980s, at a time when the government was attempting to reduce 'headline' direct tax rates.

Table 3.1

Cost to National Insurance Fund of contracting out arrangements, 1999-2000

\begin{tabular}{l|cc}
\hline \hline Type of contribution & \multicolumn{2}{|c}{ Cost } \\
& $£ b n$ & $\%$ GDP \\
\hline Occupational schemes deducted from NICs received & 6.0 & 0.7 \\
DC Occupational schemes paid direct to scheme & 0.1 & 0.0 \\
Personal pensions paid direct to insurer & 2.7 & 0.3 \\
Total & 8.8 & 1.0 \\
& & \\
\hline Increase in NI contribution rate implied by CORs: & & \\
$\quad$ If employer rate increased & 21/percentage points \\
If employee rate increased & 3 percentage points \\
\hline \hline
\end{tabular}

Note: A larger increase in the employee rate is required to raise the $£ 8.8 \mathrm{bn}$ since it is levied on a smaller range of earnings.

Source: HM Treasury (2000b; 2000c).

Moreover, in two further respects, this understates the impact on underlying tax rates of contracting-out. First private pension plans are tax-relieved relative to other saving instruments in other respects, but most notably in that they permit members to take a quarter of the accrued fund in a DC plan, or 1/2times final salary in a DB plan, as a tax-free lump sum. Emmerson and Johnson (2001) estimate that, on an expenditure tax basis, this is equivalent to around $£ 2$ billion in lost revenue, in 1998-99 prices. Second, employer contributions to pension schemes are exempt from National Insurance contributions. Therefore, as policy induced greater contractingout, it also raised payroll tax rates at the time that employers and individuals chose to contract out.

Of course, the rationale for pre-funding is that future tax rates will be lower because accrued social security pension rights are reduced. But note that, in a voluntary system of contracting-out, so long as private agents are rational, a government can never fully recoup the tax 'cost' arising in the first instance, because only individuals who gain from the switch should do so and this switching will be at the expense of government revenues in the long run. In practical terms, this implies that, in setting the contracted-out rebates (CORs), the government has had to make assumptions concerning prospective future rates of return on funded contributions such as to ensure that the private funder can pay a benefit at least as high as the social 
security benefit foregone. If the rebate is too high, some opting agents will be compensated excessively (this is the source of the retirement wealth effect described previously). Set the rebate too low, and no agent will contract out. There is plenty of evidence that the government has systematically erred on the side of generosity in order to maximise contracting out. ${ }^{29}$

However the current higher payroll tax rate is offset, and the future cost reduction enhanced, insofar as social security liabilities have been reduced over time by measures such as the decision to link pensions in payment to the growth of prices rather than the higher of prices or earnings growth, since 1981. With sustained real earnings growth over much of the period since 1981, this has reduced the value of the basic flat pension from 1981 to the present time. On current trends, the basic pension is expected to be worth less than $7 \%$ of earnings in $2050 .^{30}$

The 'burden' of the transition to greater funding of pensions in the UK is therefore shared across generations and within generations. Current pensioners bear the cost in part because state pension benefits have been cut. While current workers who remain contracted-in may well expect lower state pensions in retirement they still bear it in part because the National Insurance contribution rate is higher than it would otherwise be, and contracted-out workers in occupational pension schemes because they are generally making direct contributions to their own pension on top of their residual National Insurance contribution. ${ }^{31}$ The only group for which incidence is unclear in principal are rebate-only optants for personal pensions - that is, individuals who make no contributions other than the contracted out rebate to their personal pension. Clearly their current burden within the scheme is zero, and whether they ultimately 'pay' for the transition depends on whether their final pension is higher or lower than it would have been had they remained contracted-in to the social security system. Since it is likely to be higher, as suggested, this retirement wealth effect may have led to a reduction in their overall saving.

\footnotetext{
${ }^{29}$ See Disney and Whitehouse (1992a,b, 1993b) for details.

${ }^{30}$ This became a political 'hot potato' for the Labour government in 1999-2000, ironically as a result of the success of its anti-inflation strategy. After an increase in the basic state pension of only 75 pence per week was announced in 1999, pressure from a number of groups induced an announcement of increases in 2000 well above the rate of inflation.
} 


\section{Pension reform: distributional outcomes in the UK}

The presence of greater contracting out might be expected to lead to greater inequality for two reasons. First, private pension incomes may be more volatile than state incomes. Second because, in the 1980s and 1990s, average private pensions grew much faster than state pensions and, as we have seen, higher earners are more likely to have contracted out. Despite cutbacks in the basic pension since 1981, pensioners' incomes over the last twenty years have, on average, grown more quickly than that of the population as a whole. The net income, before housing costs, of both pensioner couples and single pensioners was some 60 per cent higher in real terms in 1996-97 than in 1979, compared to real average earnings growth over the period of 38 per cent (Department of Social Security, 2000a). This has been due to real increases in incomes from state pensions (as SERPS gradually matured after its introduction in 1978), means-tested benefits, occupational pensions and investments (Department of Social Security, 2000c).

This real increase in pensioner incomes has led to pensioners now being under represented in the poorest ten per cent of the population, which since the start of the 1970s has tended to be occupied by other unwaged groups such as the unemployed and single parents (Goodman and Webb, 1994). They are still over represented in the bottom half of the income distribution. ${ }^{32}$ These real increases in incomes have not however been evenly spread across the pensioner distribution. Johnson and Stears (1995) show that while income inequality among pensioners fell from the early 1960s to the late 1970s, it rose sharply during the 1980s. This was caused by a combination of an increase in the inequality of income from investments and private pensions. Growing inequality alongside growing average real incomes is shown in figure 4.1 which gives gross incomes for pensioner couples in 1979 and 1998-99, by income quintile, at July 1998 prices.

\footnotetext{
31 Some public sector occupational schemes have not levied employee contributions to cover prospective liabilities, but there is a trend towards more transparent contribution arrangements in such schemes (Cabinet Office, 2000).

${ }^{32}$ Of course it could be the case that due to dissaving consumption by the retired was actually much higher then their current incomes. However, as discussed in Banks, Blundell, and Tanner (1998), upon retirement consumption actually tends to fall faster then income.
} 
How do these levels and trends in pensioner inequality compare to other countries? A number of country-specific studies in Disney and Johnson (2001) yield three broad conclusions. First, as in the UK, pensioners are typically overrepresented in the lower half of the equivalised income distribution, but underrepresented in the lowest quintile of the income distribution. Second, income inequality among pensioners is typically greater in countries that offer comprehensive earnings replacement (the 'Bismarck' system) than in countries where the state focuses on providing a benefit 'floor' (the 'Beveridge' system). This is true even when private sources of income are included. Third, there are no common trends in inequality of pensioner incomes across countries.

\section{Figure 4.1. Components of gross weekly income of each quintile of the pensioner couples income distribution, 1979 and 1998-99, July 1998 prices}

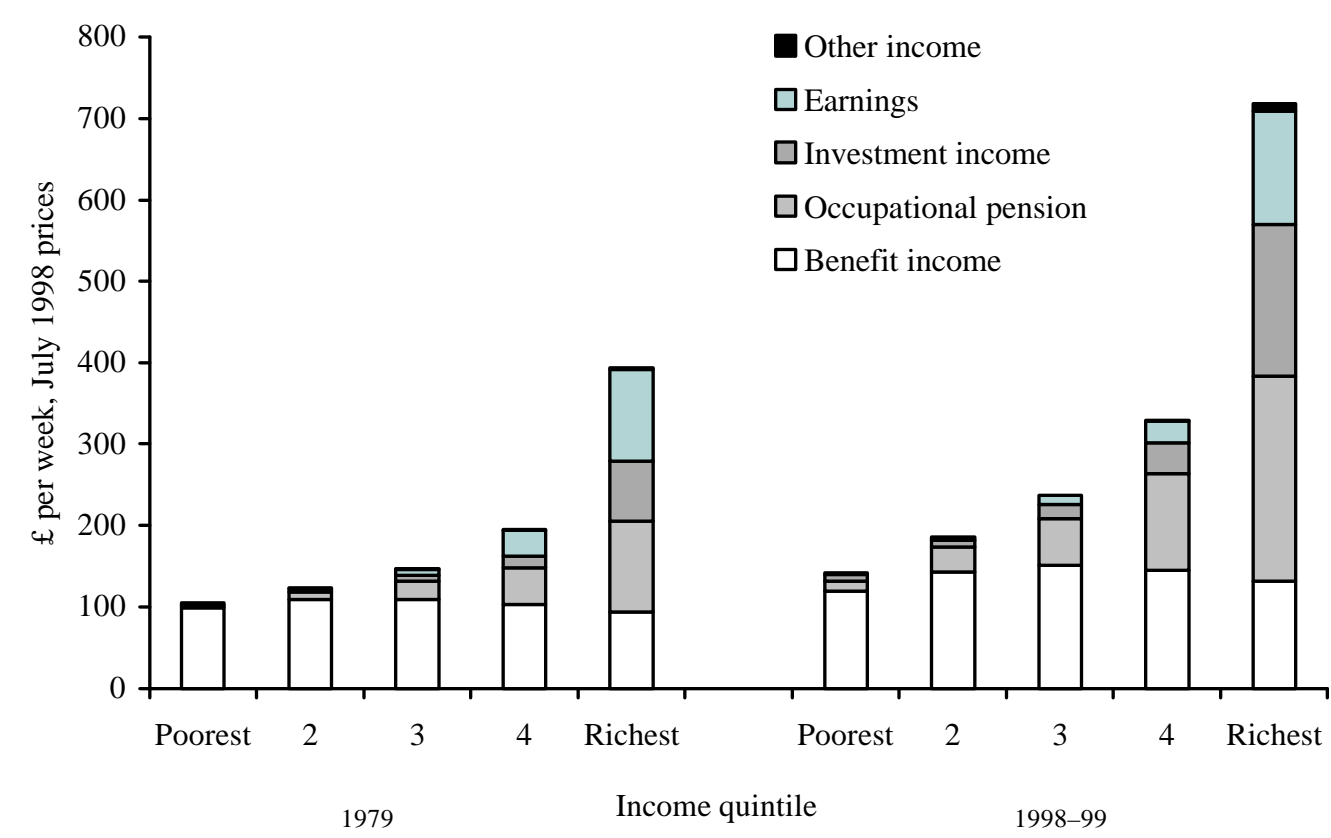

Source: Department of Social Security (2000a) using data from the 1998-99 Family Resources Survey and the 1979 Family Expenditure Survey. Clark and Taylor (2000) show that valid comparisons can be made between the two surveys.

\section{Labour supply and retirement: impact of pension reform}

Research into labour supply of the elderly, and the role of tax and pension reforms in the 1980s and 1990s, has been fairly limited in the UK, unlike the US. In any event, a number of retirement issues lie outside the scope of the present paper. A 
comprehensive survey of data and sources on retirement is contained in Blundell and Johnson (1999); more specific accounts of and possible explanations for the decline in labour force participation over the period of the 1980s and 1990s are contained in Dilnot et al (1994) and Disney (1999). Again, three salient conclusions emerge from these discussions.

First, there has been a steady decline in the labour force participation of older men, punctuated by more rapid falls in the recessions that characterised the beginning and end of the 1980s. On the demand side, the massive restructuring of the economy and the lack of appropriate skills of older workers probably contributed to this decline. On the supply side, the decline in participation was facilitated by the early retirement provisions of occupational pension schemes and by the operation of the public scheme of disability benefits. ${ }^{33}$ The decline in the percentage of older men who are full-time employees is shown in figure 5.1. As shown in Disney (1996) this is not due to individuals reducing their hours but instead due to falling employment among older age groups. Indeed final salary occupational pension schemes encourage individuals to remain full time until they retire. ${ }^{34} \mathrm{~A}$ fuller discussion of these issues is contained in Blundell, Meghir and Smith (2001).

\footnotetext{
${ }^{33}$ Invalidity Benefit, subsequently renamed Incapacity Benefit.

34 Although self-employment may be another 'route' out of employment (Disney, Meghir and Whitehouse, 1994).
} 
Figure 5.1. Percentage of older men and women who are full-time employees, by age group, 1968 to 1999.

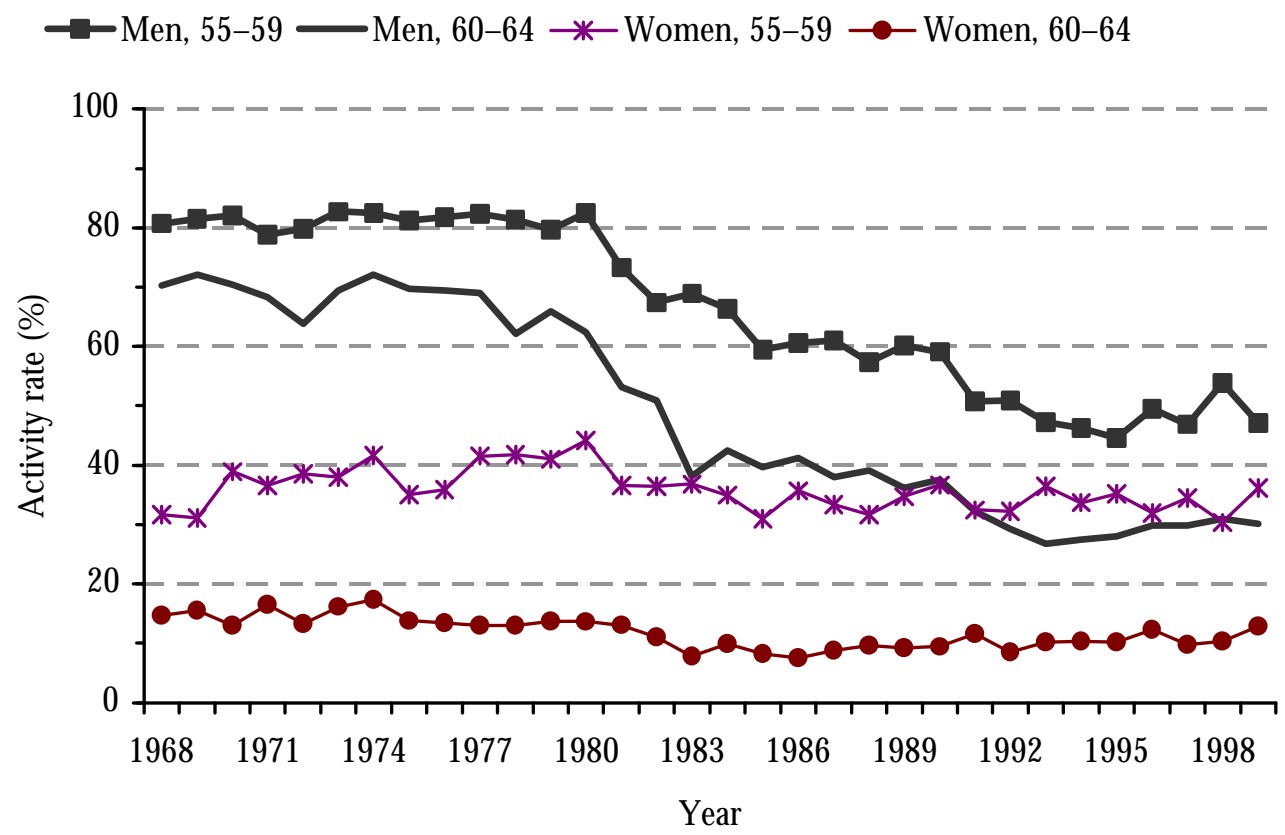

Source: Family Expenditure Survey D ata from 1968 to 1999.

Second, there is no explicit early retirement provision within the public pension scheme. Nevertheless, efforts have been made to tighten other 'routes' into retirement before state pensionable age (65 for men and, from 2020, for women). Eligibility for disability benefits was tightened in the late 1990s, and the benefit made taxable, cutting its value to that of the basic state pension. Also, in an attempt to encourage employment among older workers, in 1989 the earnings test condition for receipt of the basic state pension, for earners above state pensionable age, known as the 'earnings rule', was abolished. Disney and Smith (2000) estimate that this change significantly raised the hours of working men aged 65 and above, but not participation rates nor the hours of women. Moreover, the government has become increasingly concerned as to the early retirement practices of occupational pension schemes, especially those covering public sector workers such as local and central government workers, police, firecrews etc. ${ }^{35}$ It seems likely that further limits will be placed on early retirement on actuarial favourable terms and on grounds of ill health in these schemes.

\footnotetext{
${ }^{35}$ See Audit Commission (1997) and HM Treasury (2000d) for more details.
} 
Finally, however, the most pertinent issue for this paper concerns the impact on retirement behaviour of the introduction of personal pensions and other new contracting out arrangements. Since the majority of personal pension optants are young (Figure 2.2) and are still some way away from their likely retirement date, there is no evidence on the effects in practice. Basic economic principles suggest that there are both wealth and substitution effects here that rule out a definitive outcome $a$ priori. The picture is further complicated by the fact that these incentive effects are likely to differ for someone moving from SERPS to a personal pension and someone moving from DB scheme to a personal pension (or DC occupational scheme).

To the extent that personal pensions provide a positive retirement wealth effect relative to remaining in the public scheme (SERPS), then this might induce individuals to retire earlier than they would otherwise have done (although they could not draw SERPS until reaching state pensionable age). On the other hand, the incentive of a higher return on contributions to personal pensions than the implicit return on contributions to a social security scheme (or, with actuarially favourable early retirement, in an occupational pension scheme) might induce personal pension optants to defer retirement. Of course, contributions made to a personal pension close to retirement are not as valuable as those made at the start, but since people with personal pensions must annuitise between the ages of 50 and 75, they can continue to build up their fund (through increased contributions or capital gains) past the state pensionable ages. For someone in SERPS, years worked past 65 for men (and 60 for women) do not yield further pension benefits. Compared to someone in a DB occupational scheme where the last years of work are fairly crucial in determining subsequent pension entitlement, the option value of delaying retirement and contributing to a personal pension for another year be quite a lot lower - the first years' contributions matter much more. This effect would tend to encourage people to retire earlier, but could be mitigated to the extent that people in DB schemes are encouraged to leave when their salary is at its highest point and to the extent that personal pensions allow individuals much greater flexibility.

However, as the next section will show, there is a good deal of mobility between pension scheme types, and it is very likely that those currently contributing to a personal pension may, later in life, be in an occupational pension scheme or even 
revert to the social security scheme. Thus no firm conclusions can yet be drawn on this important issue.

\section{Labour market flexibility}

\subsection{Pensions and labour mobility}

One of the implicit motivations for introducing more flexible contracting out arrangements was that personal pensions, in particular, would be attractive to young, mobile, workers. Greater mobility between jobs and occupations would, it was hoped, enhance the restructuring of the UK economy that was needed after the meltdown of many traditional sectors, especially in manufacturing industry, in the early 1980s. At the same time, insofar as contributions to defined benefit occupational pensions represented a burden on business, the relative flexibility of defined contribution arrangements with, for example, no requirement that the employer need contribute to plans, might permit current wages more fully to reflect differences in current productivity and provide greater incentives on the margin for workers and employers to find productive 'matches'. Much of this reasoning was never made explicit. Nor was the more general perspective that individualised pensions, along with privatisations financed by public share issues, would generate a culture of individual share ownership and individual risk-taking which would move the UK away from the 'Eurosclerotic' model towards the entrepreneurial model associated, rightly or wrongly, with the United States and some Asian economies.

This issue of pension arrangements and labour mobility has not received so much attention in the UK debate concerning personal pensions, and we focus on it in this section of the paper. We examine the theory and existing empirical evidence on how different types of pension scheme affect labour mobility. Then we look at some of the empirical evidence - not so much as a test of whether pension type affects labour mobility (where we infer that the existing literature is fairly inconclusive), but rather as to who took out a personal pension and whether opting into a personal pension (especially where the employee was also offered membership of a defined benefit occupational pension plans) was associated with subsequent job mobility.

\subsection{Theory on pension schemes and labour mobility}


In looking at the impact of (private) pension arrangements on job mobility, it is important to differentiate between mobility in and out of pensioned jobs, in contrast to mobility between pensioned jobs that involve a change of pension plan. There are very good reasons why mobility out of jobs covered by pension plans may be a good deal lower than mobility of uncovered workers. The issue is examined in the United States by Gustman and Steinmeier (1993) who use the Survey of Income and Program participation (SIPP) to show that pension mobility is much lower for people in jobs with private pensions. In a three-year period (1984-86) they found that $6 \%$ of those initially in pensioned jobs moved jobs compared to $20 \%$ in non-pensioned jobs. Of those who moved out of a pensioned job, $64 \%$ moved to a job without a pension and, furthermore, they incurred an average loss of wages of $6 \%$ by moving. In contrast, $14 \%$ of movers out of uncovered jobs gained pension coverage by moving and all movers previously in uncovered jobs gained on average $7 \%$ wages by moving. This highlights the fact that there are strong deterrents to moving out of a pensioned job per se, which should be separated from the 'costs' arising from moving between pensionable jobs associated with non-portability of pensions.

The fact that people in the UK can opt not just out of social security but also out of an existing occupational pension plan potentially allows us to separate mobility that is associated with choice of pension arrangements from mobility associated with the nature of pensioned jobs. But it also raises very clearly the more general problem with studies of pension coverage and labour mobility: that of self-selection. There may be large costs, as in the SIPP example above, to moving in and out of the pension-covered sector, and between pensioned jobs, so pension arrangements affect the mobility incentives of employees. But it is also likely that employers who offer pensions will select employees on the basis of their assessed propensity to move between jobs and that employees will also select jobs on the basis of job-specific costs of mobility. Indeed, non-random selection of employees is central to any rationalisation of why employers provide pensions at all (Lazear, 1979; Ippolito, 1997).

This caveat applies particularly to the UK, where moving pension plan need not involve changing job at all. The individual 'opting out' strategy is likely to be followed by those most inclined to move between jobs, who thereby require a more 'portable' pension arrangement. So while it is possible, by comparisons across 
countries and over time, to ask whether more 'flexible' pension arrangements are associated with greater labour mobility, ${ }^{36}$ at the microeconomic level we may be observing pure selection in the UK, rather than the impact of institutional arrangements on behaviour.

The basic theory on pension schemes and the costs of job mobility is summarised in Bodie, Marcus and Merton (1988), Lazear and Moore (1988) and Ippolito (1997). We focus here in particular on the incentives associated with job mobility between pension covered jobs (not for example, those incentives associated with retirement). As illustrated by Gustman and Steinmeier (1993), the costs of moving from a covered to an uncovered job are both larger and more transparent. As we shall see, in essence, portability costs in DB plans basically depend on how benefits in past plans are treated whereas portability costs in DC plans are largely (but not exclusively) start-up costs.

For individuals moving between jobs within the sector covered by defined benefit pension plans, the loss from job mobility arises from the loss of additional years of service and final salary in the original plan. It depends on the loss at the time of moving in the original pension scheme from the lower final salary value, which depends on prospective job tenure ${ }^{37}$ For a person shifting to, say, a personal pension, the loss function is more complex. It requires comparing subsequent loss of coverage by a DB plan (although this may be reversible later), offset by the pension obtained from the contributions to the DC plan after that time. It is often argued that the costs of leaving a DB plan are high because an employer typically contributes to a DB plan and, by leaving the plan, the employee loses these additional contributions. An individual simply leaving a DB plan to buy a personal pension is presumably unable to compensate for this loss of contributions but, for job movers, the absence of employer pension contributions (deferred pay) ought to be compensated by higher current pay. On the other hand, if, ceteris paribus, DB plan providers actually also

\footnotetext{
${ }^{36}$ And even this cross-country or temporal 'experiment' may be problematic - the reforms which permitted greater 'flexibility' in pension arrangements in the UK in the 1980s may have themselves been stimulated by the greater flexibility of the UK labour market in other dimensions, such as the decline of trade unions, shift towards private services and away from manufacturing and the public sector, and so on.

${ }^{37}$ Most literature overstates this loss by assuming that the individual would otherwise have remained in the DB plan until retirement. The implausibility of this assumption in valuing DB pension plan rights in the UK is demonstrated by Disney and Whitehouse (1996).
} 
pay higher wages (as suggested by Gustman and Steinmeier, 1993) then the costs of leaving the covered sector - both in lost pension and wages would be considerable.

In principle, as suggested above, defined contribution plans such as personal pensions are fully and costlessly transferable. In practice, the issue is a little more complex. Where the existing personal pension (PP) plan 'lapses' because the individual starts another PP plan, joins an occupation pension scheme or indeed reverts to SERPS, the social security benefit a costs will typically arise because personal pensions often have an up-front commission charge which is deducted from early contributions. For example, if the personal pension is only held for a short duration, then insufficient funds may have been invested in the plan, net of commission, to recoup the gross cost of contributions in the early stages. This is clearly one of the reasons why the government has decided that stakeholder pensions will only be able to charge a percentage of the fund, rather than having up-front or exit charges. In addition individuals with a personal pension who move job will lose out if the previous employer was contributing to the personal pension and the new employer is not prepared to, or to compensate in any other way.

There has been a certain amount of controversy in the UK on this issue, since the initial regulator (the Personal Investment Authority, now subsumed into the Financial Services Authority) has produced evidence both of high rates of lapse (since most individuals opting for personal pensions are young - see section 2.3 above) and of high administrative costs. Murthi, Orszag and Orszag (1999) therefore argue that, under certain circumstances, the 'mobility costs' associated with personal pensions may be higher than for 'traditional' defined benefit plans. Since personal pensions were introduced precisely to enhance labour mobility, this is a worrying conclusion. However, Whitehouse (2000) takes issue with the conclusion, arguing (i) that the extrapolation of lapse rates by Murthi et al (1999) from published data overstates the likely rate of lapsing, ${ }^{38}$ and (ii) that the 'costs of mobility' in such plans are highly sensitive both to measures of administrative costs and of the subsequent labour market trajectory and contribution behaviour of personal pension optants. Many individuals, for example, fail to contribute to a personal pension for a year or more, only to

\footnotetext{
${ }^{38}$ Essentially, the authors adopt a parametric specification of the implicit hazard which overstates the rate at which individuals exit personal pension plans relative to, say, a non-parametric specification such as the Kaplan-Meier.
} 
contribute later. This can of course be explored using panel data such as the British Household Panel Study.

\subsection{Past empirical evidence on labour mobility and pension schemes in the UK}

McCormick and Hughes (1984) see the problem as one of estimating firm specific pension capital as \% of pension capital. They study the loss of pension capital from moving between (DB plan) pensionable jobs. At the time that they wrote, there were three options concerning moves between covered jobs: benefits could be deferred (preserved), a cash refund of contributions could be obtained, or there could be a transfer value into the new scheme. McCormick and Hughes work out the relative costs neatly and show that these alternative options are optimal at different points in the working life and that the 'envelope' loss-minimising function is nonlinear with pension scheme tenure.

To implement the model empirically, they use a General Household Study (GHS)-based measure of job turnover. They also have measures of job satisfaction and a GHS question 'are you (the worker) seriously considering changing employer'? Note that we do not observe which option the worker chooses, and that the authors are essentially trying to model the non-linearity of mobility with tenure, assuming that this reflects the 'envelope' constructed above. Furthermore, McCormick and Hughes largely use the attitudinal question as their dependent variable. They assume that the 'opportunity' job also has a pension scheme so the costs are pure scheme-specific rights, not loss of pension rights per se, and abstract from any questions of compensating changes in wages.

The explanatory variables in their modelling strategy for 'are you seriously considering changing job' are personal characteristics, job satisfaction and interactions of pension status, job tenure and age which are supposed to capture the non-linearity of the loss function (a simple dummy for pension scheme membership is insignificant). The results all hinge on the coefficient on years of job tenure*pension status, with job tenure not included as an independent regressor. Since we know from other studies that search is (negatively) affected by tenure, this can be interpreted as suggesting that tenure matters only in pensionable jobs and the coefficient is indeed significant. 
Criticisms of the modelling procedure include that the paper is largely about intent to move, not actual turnover. The rationale for this is somewhat tortuous and perhaps the model does not work for actual job exits. The authors point to the selfselecting nature of job exits but it is not clear that the attitudinal variable avoids this problem. In addition, they know nothing about the type of pension scheme. Finally, it seems as if the predicted theoretical shape of the loss function (the envelope) is not that estimated by the econometrics - they are both quadratic in tenure but the curvature seems to be the 'wrong way' in the results.

Henley, Disney and Carruth (1994) adopt a different approach. The object is to see whether assets holdings affect job tenure, such as owning a house, belonging to a pension scheme, and so on. The authors argue that a better identifier of the impact of pensions on job mobility, given self-selection, is whether the particular characteristics of a pension scheme have an impact on the propensity to move. Of course, it is still possible that individuals self-select into the type of pension scheme according to their implicit moving probabilities, but this may require a more sophisticated calculus than a simple membership decision. ${ }^{39}$

The empirical strategy involves using reported job tenure intervals to construct the hazard rather than a binary variable approach, using the 1985 General Household Survey. The truncation of the duration intervals and the measures of housing equity (observed only for house movers) involves some standard econometric procedures for handling censored data. A key finding is that occupational pension scheme membership significantly decreases the exit hazard from jobs, but reported transferability of pension rights increases it (on the basis of observed completed spells) relative to simple pension scheme membership. Moreover the effect on the hazard rate of membership interacted with time (duration) and time squared is superior to a simple dummy, confirming the McCormick-Hughes proposition that the loss function is time dependent and possibly non-linear. In fact (for men) Henley et al get a result that approximates the curvature of the McCormick-Hughes theoretical loss function in contrast to the latter's empirical results.

\footnotetext{
${ }^{39}$ But since the characteristics are self-reported, a natural criticism is that these characteristics are known, even if not understood.
} 
Mealli and Pudney (1996) is the only UK paper that attempts to look at the endogeneity of pension status, but it does so indirectly. It uses the job histories and pension scheme tenures in the Retirement Survey to model transitions. Obviously the permutations of possible multiple state transitions are large over the lifetime, so their paper essentially uses a competing risks model to examine transitions between various states (e.g. a pensioned job, non-pensioned job, unemployment etc.) conditional on treating the initial state as exogenous (but see below). Note that transitions between pensioned jobs but with different pension schemes (which is the basis of the McCormick-Hughes model of job-specific pension capital) are ignored. So this is not a test of job-specific pension capital impact but of the impact of pension coverage on tenure, like Gustman and Steinmeier (1993). Their finding is that job durations are systematically longer for pensioned jobs.

The question, however, is whether this is unobserved heterogeneity of participants or a consequence of pension status. Essentially their 'technical' solution is not to find some 'instruments' for individual fixed effects (even if any could be found that were plausible) but to add state specific random effects into the competing risks model. By specifying various forms of heterogeneity (individual effects, random effects, random effects*sectoral status, etc.) the object is to see whether the differences in duration between pensioned and non-pensioned jobs are eliminated, and their overall answer appears to be that the differences are not wholly eliminated (Table VIII, ibid). So there may be a 'pension coverage effect' after all.

Overall, the findings of the UK studies are:

i) that the theoretical relationship between job-specific pension capital and tenure is non-linear;

ii) that (DB) pensionable jobs have longer durations;

iii) this is not wholly due to heterogeneity (self-selection);

iv) transferable pension rights are associated with more job mobility;

v) that there appears to be a non-linear relationship between duration and the 'pension effect' in DB plans.

6.4 Evidence on personal pensions and job mobility 
Our aim in this section of the paper is to provide a preliminary empirical analysis of the link between individuals' pension arrangements and their labour market mobility. We will exploit the feature of the UK institutional arrangements that allows individuals who are offered an occupational pension to opt out of the scheme and choose their own personal pension. Our strategy is to compare the job mobility of people who are offered a DB occupational scheme and choose not to be in it with the job mobility of people who do belong to the DB occupational pension scheme offered. Clearly there will be a degree of self-selection by individuals into the two groups according to their future job mobility. At this stage, therefore, our analysis is not intended to provide an estimate of the impact of the introduction of personal pensions on job mobility. Rather, it will shed light on two issues. Firstly, it will allow us to examine the extent to which individual pension choices appear to be motivated by job mobility. Secondly, it will allow us to address the arguments of Gustman and Steinmeier (1993) and separate the potential effects of the pension arrangements on job mobility from other aspects of the job.

To examine these issues we use data from the British Household Panel Survey. This is a panel survey that has been following the same individuals over time since 1991. We use data from waves two through eight (1992 - 98 inclusive). The BHPS collects detailed information on individuals' employment and their socioeconomic characteristics. It also contains a number of questions about their pension arrangements. The survey asks,

Does your present employer run a pension scheme or superannuation scheme for which you are eligible?

If the answer is yes, respondents are then asked

Do you belong to your employer's pension scheme?

In addition, from the second wave onwards all respondents are asked questions about their personal pension arrangements.

In the past year, that is since September 1st 1991 have you paid any contributions or premiums for a private personal pension, or had such contributions paid on your behalf by the Department of Social Security?

If the answer to this is yes, they are asked to say whether they took out the pension before or after June 1988 and the year they first took out the pension. They 
are also asked whether they have made any additional contributions, over and above the contracted out rebate and how much the last contribution was.

The advantage of the BHPS data is that it allows us to identify those people who were offered a pension scheme by their employer but chose instead to have their own personal pension. Also, it allows us to identify those people who were offered a pension by their employer and chose to participate in the scheme. The main part of our analysis will focus on differences in the labour market mobility between these two groups. However, there are a number of respects in which the definition of these groups is not as clean as we would like.

In particular, individuals are not asked whether their employer offers them an occupational pension scheme. Rather, they are asked about any pension scheme offered by their employer. This might include people who are offered group personal pension schemes. We should be able to identify these people since they are likely to report that they are offered a pension scheme to which they belong and that they have a personal pension. We might therefore want to classify anyone who reports having a personal pension as not having an occupational pensions. However, adopting this strategy might lead to us wrongly excluding some people who are in their employers' DB occupational pensions, but also say yes to the personal pension question because they are making additional contributions in the form of Free Standing Additional Voluntary Contributions.

Also, we cannot distinguish between DB occupational pension plans and DC occupational pension plans. In total, nearly 15 per cent of all occupational pension schemes, and a higher proportion in the private sector, are DC schemes, as shown in table 6.1. Incorrectly including people who actually belong to DC occupational pension schemes with people who belong to DB occupational schemes is likely to underestimate the effect to which people opt out of occupational pension schemes with a view to future labour market mobility. ${ }^{40}$

\footnotetext{
${ }^{40}$ But note that Gustman and Steinmeier find no evidence that mobility is affected by whether the employer's plan is of the DB or DC form.
} 
Table 6.1. Occupational pension schemes, by type

\begin{tabular}{l|ccc}
\hline & $\begin{array}{c}\text { \% private sector } \\
\text { schemes }\end{array}$ & $\begin{array}{c}\text { \% public sector } \\
\text { schemes }\end{array}$ & \% all schemes \\
\hline Defined benefit plans & 78 & 98 & 80 \\
Defined contribution plans & 16 & 2 & 14 \\
Hybrid & 6 & - & 6 \\
\hline Seurce: Nationa & &
\end{tabular}

Source: National Association of Pension Funds Annual Survey of Occupational Schemes, 1997

A final issue concerns the 'mis-selling' of personal pensions that took place in the late 1980s. This suggests that a substantial number of people chose to leave their employers' occupational scheme due to bad financial advice. This will tend to reduce any observed correlation between the decision to have a personal pension instead of an occupational pensions and future employment mobility.

Bearing these factors in mind, we now turn to our analysis of the data in the BHPS. Our analysis is based on the sample of individuals who are aged between 20 and 59 in the first wave of the BHPS and who are present in all eight waves. Table 6.2 compares the pension status of employees in the BHPS in 1992 with that of those in the General Household Survey (GHS) which is a larger annual cross-sectional sample containing just under 9,000 employees in 1992.

Looking first at whether an employer offers a pension scheme, around seventy per cent of individuals are able to join an employers pension scheme in each of the two surveys. The BHPS has slightly larger levels of membership of these schemes with seventy six per cent of those eligible joining their employers scheme compared to sixty nine per cent in the GHS. The table shows that pension coverage appears to be greater in the GHS than in the BHPS. This points to some potential selection caused by non-random attrition over the eight waves of the BHPS. Finally, individuals in the BHPS who claim to be both a member of their employers pension scheme and a member of a personal pension could either be individuals who have a group personal pension or those who have an occupational pension and are making additional voluntary contributions to that pension. 
Table 6.2. Pension status of employees in 1992

\begin{tabular}{l|cc}
\hline & BHPS & GHS \\
\hline \% of employees offered an employers pension & 69 & 72 \\
$\%$ of those offered that joined an employers pension & 75 & 69 \\
Men full time & & \\
\% without a private pension & 17 & 11 \\
$\%$ in an employers pension scheme & 55 & 62 \\
$\%$ in a personal pension scheme & 17 & 27 \\
$\%$ in both an employers pension scheme and a personal pension & 11 & - \\
Observations & 1,252 & 4,311 \\
& & \\
Women full time & & 25 \\
$\%$ without a private pension & 29 & 54 \\
$\%$ in an employers pension scheme & 47 & 21 \\
$\%$ in both an employers pension scheme and a personal pension & 16 & - \\
Observations & 8 & 2,396 \\
Women part time & 907 & \\
$\%$ without a private pension & & \\
$\%$ in an employers pension scheme & & \\
$\%$ in a personal pension scheme & 71 & 68 \\
Observations & 17 & 19 \\
\hline
\end{tabular}

Note: BHPS data includes individuals aged 20 to 59 in 1991 who are present in all eight waves only and not self-employed in any wave; GHS data includes all employees aged 16 and over apart from those in Youth Training or Employment Training schemes.

Source: British Household Panel Survey, 1992 to 1998 inclusive; authors' calculations; HMSO (1994).

Table 6.3 considers how pension coverage has changed over the seven waves of the BHPS. Interestingly the proportion of individuals choosing to join their employers pension scheme rose from around three-quarters in waves 2,3 and 4 to over four-fifths of those offered schemes in the eighth wave. As a result of this, and a slight increase in the number of employers offering pension schemes there is an increase in membership of employer schemes over the period.

The proportion who were able to join an employers pension scheme but instead choose to join a personal pension fell from around ten per cent between 199294 to just over five per cent in 1998. This is possibly evidence of individuals learning from the 'mis-selling' experience outlined above. Of those who declined to join their employers pension scheme just over seventy per cent had no pension arrangement (and by default those with earnings above the Lower Earnings Limit (LEL) would be in SERPS) with the remaining thirty per cent in a personal pension. These percentages remained very stable over the eight waves of the BHPS used for this study. 
Table 6.3. Pension status of employees only, by wave

\begin{tabular}{|c|c|c|c|c|c|c|c|}
\hline & \multicolumn{7}{|c|}{ Wave (1992 to 1998 ) } \\
\hline & 2 & 3 & 4 & 5 & 6 & 7 & 8 \\
\hline$\%$ of individuals offered an OP & 69.4 & 66.7 & 66.0 & 69.6 & 71.5 & 72.7 & 72.6 \\
\hline$\%$ of those offered that joined an OP & 75.5 & 75.9 & 75.2 & 78.9 & 80.3 & 81.4 & 83.1 \\
\hline \multicolumn{8}{|l|}{ All individuals } \\
\hline$\%$ without a private pension & 32.7 & 33.5 & 34.3 & 30.5 & 29.5 & 28.2 & 27.8 \\
\hline$\%$ with occupational pension & 44.4 & 41.8 & 41.4 & 46.7 & 49.4 & 50.1 & 51.2 \\
\hline$\%$ with personal pension & 14.9 & 16.0 & 16.0 & 14.6 & 13.0 & 12.7 & 11.9 \\
\hline$\%$ with both OP and PP & 8.0 & 8.7 & 8.3 & 8.2 & 8.1 & 9.1 & 9.1 \\
\hline Observations & 2,778 & 2,765 & 2,750 & 2,732 & 2,713 & 2,693 & 2,650 \\
\hline \multicolumn{8}{|l|}{ All individuals offered an OP } \\
\hline$\%$ without a private pension & 15.0 & 13.8 & 15.2 & 12.8 & 13.2 & 12.4 & 11.7 \\
\hline$\%$ with occupational pension & 63.9 & 62.8 & 62.7 & 67.1 & 69.0 & 68.9 & 70.5 \\
\hline$\%$ with personal pension & 9.5 & 10.3 & 9.6 & 8.3 & 6.5 & 6.2 & 5.2 \\
\hline$\%$ with both OP and PP & 11.6 & 13.1 & 12.6 & 11.8 & 11.3 & 12.5 & 12.6 \\
\hline Observations & 1,928 & 1,843 & 1,816 & 1,902 & 1,941 & 1,958 & 1,923 \\
\hline \multicolumn{8}{|l|}{ All individuals not offered an OP } \\
\hline$\%$ without a private pension & 72.8 & 72.8 & 71.4 & 71.0 & 70.6 & 70.2 & 70.3 \\
\hline$\%$ with occupational pension & - & - & - & - & - & - & - \\
\hline$\%$ with personal pension & 27.2 & 27.2 & 28.6 & 29.0 & 29.4 & 29.8 & 29.7 \\
\hline$\%$ with both OP and PP & - & - & - & - & - & - & - \\
\hline Observations & 850 & 922 & 934 & 831 & 772 & 735 & 727 \\
\hline
\end{tabular}

Note: Includes individuals aged 20 to 59 in 1991 who are present in all eight waves only and not selfemployed in any wave.

Source: British Household Panel Survey, 1992 to 1998 inclusive; authors' calculations.

Also of interest is the frequency of individual pension membership changes over the period of the study. Changes in pension status are in fact extremely common, as shown in table 6.4. This adds complexity to our study since individuals cannot be easily identified as someone who has a certain pension type. Of those with no pension arrangement in 1992 only sixty per cent were not in a pension scheme in 1998. Of those who were contributors to personal pensions in wave 2 , only $42 \%$ were contributors in 1998. But membership of occupational pensions is relatively more stable. Some 79 per cent of those in an occupational pension scheme in 1992 were a member of an occupational pension scheme in 1998.

This is a striking finding for policy. Some official publications (such as Department of Social Security, 1998) have suggested that certain types of pension scheme should be matched to certain types of individuals - in particular, by income level. While pension scheme mobility may therefore also reflect income volatility and income mobility, excessive multiplicity of individual pension scheme membership within the working lifetime probably results in reduced pension benefits due to start- 
up costs (in personal pensions prior to the introduction of stakeholder pensions in 2001) and capital losses (from moving out of DB plans). Offsetting this is the possibility that multiple pension holding may have some positive insurance characteristics if the risk properties of different pension types vary (Brugiavini and Disney, 1993).

Table 6.4. Pension transitions, by wave, (employees in wave 2 only)

\begin{tabular}{|c|c|c|c|c|c|c|c|}
\hline & \multicolumn{7}{|c|}{ Wave (1992 to 1998$)$} \\
\hline & 2 & 3 & 4 & 5 & 6 & 7 & 8 \\
\hline \multicolumn{8}{|l|}{ Has no pension in wave 2} \\
\hline$\%$ without a private pension & 100.0 & 84.8 & 80.7 & 68.1 & 65.3 & 61.0 & 59.5 \\
\hline$\%$ with occupational pension & & 3.4 & 4.6 & 17.0 & 20.3 & 25.6 & 26.4 \\
\hline$\%$ with personal pension & & 11.5 & 13.8 & 12.7 & 12.6 & 11.7 & 10.7 \\
\hline$\%$ with both OP and PP & & 0.3 & 0.9 & 2.3 & 1.9 & 2.8 & 3.4 \\
\hline \multicolumn{8}{|l|}{ Has occupational pension in wave 2} \\
\hline$\%$ without a private pension & & 3.5 & 6.3 & 9.2 & 8.5 & 9.3 & 10.8 \\
\hline$\%$ with occupational pension & 100.0 & 86.2 & 84.0 & 81.7 & 82.6 & 80.1 & 79.4 \\
\hline$\%$ with personal pension & & 0.5 & 0.6 & 0.8 & 1.2 & 1.7 & 2.0 \\
\hline$\%$ with both OP and PP & & 9.8 & 9.2 & 8.4 & 7.7 & 8.9 & 7.9 \\
\hline \multicolumn{8}{|l|}{ Has personal pension in wave 2} \\
\hline$\%$ without a private pension & & 16.4 & 19.5 & 17.4 & 21.9 & 20.0 & 19.5 \\
\hline$\%$ with occupational pension & & 0.7 & 3.6 & 11.8 & 16.9 & 23.4 & 25.8 \\
\hline$\%$ with personal pension & 100.0 & 81.2 & 74.5 & 62.2 & 50.6 & 45.8 & 41.9 \\
\hline$\%$ with both OP and PP & & 1.7 & 2.4 & 8.7 & 10.6 & 10.8 & 12.8 \\
\hline
\end{tabular}

Note: Includes individuals aged 20 to 59 in 1991 who are present in all eight waves only and not selfemployed in any wave.

Source: British Household Panel Survey, 1992 to 1998 inclusive; authors’ calculations.

Finally, we turn to a provisional assessment of the impact of labour market status on job mobility. Table 6.5 shows the percentage of individuals who move jobs between each wave of the BHPS by their pension status in the previous wave. In total just over one third (36.6 per cent) of employees in wave 2 move job at least once over the period of interest. The first part of table 6.5 shows that it is those individuals without a pension and those with a personal pension in the previous wave who are more likely to have moved employer, rather than those who are members of their employers pension scheme. However this could simply reflect the fact that occupational pensions may be offered in the types of industries or to types of people who have lower rates of job mobility. A better indicator of whether individuals with personal pensions are more likely to move jobs is shown in the next part of table 6.5 which looks at just those individuals who were offered occupational pension schemes. 
Over the period of this study between 7.6 and 13.0 per cent of those who chose to take out a personal pension rather than join their employer's occupational pension moved job in the subsequent year. Of those who chose to 'default' to SERPS, the fractions moving, ranging from $9.3 \%$ to $17.9 \%$, are even higher. This contrasts with between 3.6 and 6.7 per cent mobility for individuals who joined the occupational pension scheme. Looking at those who move employer at any point over the period 42.9 per cent of those who choose not to join their employers pension scheme in favour of a personal pension moved job compared to 27.4 per cent among those who did join their employers scheme. This 15.5 percentage point difference has a standard error of 3.6 and hence is highly significant. This clearly suggests that those individuals who chose to 'opt-out' of their employers pension scheme for a personal pension or SERPS were indeed more likely to move employer subsequently. 
Table 6.5. Percentage of people changing employer, by pension status in previous wave, (employees in wave 2 only)

\begin{tabular}{|c|c|c|c|c|c|c|c|}
\hline \multirow[t]{2}{*}{ Pension status in previous wave } & \multicolumn{6}{|c|}{ Wave } & \multirow{2}{*}{$\begin{array}{l}\text { Any } \\
\text { move }\end{array}$} \\
\hline & 3 & 4 & 5 & 6 & 7 & 8 & \\
\hline All individuals & & & & & & & \\
\hline$\%$ without a private pension & 12.4 & 15.3 & 15.9 & 17.6 & 16.4 & 17.6 & $\begin{array}{l}46.9 \\
(1.7)\end{array}$ \\
\hline$\%$ with occupational pension & 3.6 & 6.7 & 5.8 & 6.6 & 5.7 & 6.1 & $\begin{array}{l}27.4 \\
(1.3)\end{array}$ \\
\hline$\%$ with personal pension & 10.6 & 15.6 & 12.0 & 14.9 & 16.8 & 13.1 & $\begin{array}{l}46.5 \\
(2.5)\end{array}$ \\
\hline$\%$ with both $\mathrm{OP}$ and $\mathrm{PP}$ & 4.9 & 8.1 & 3.9 & 5.3 & 6.7 & 8.0 & $\begin{array}{l}26.5 \\
(3.0)\end{array}$ \\
\hline All & 7.6 & 11.0 & 10.2 & 10.9 & 10.3 & 10.3 & $\begin{array}{l}36.6 \\
(0.9)\end{array}$ \\
\hline $\begin{array}{l}\text { Individuals offered an occ. pen. } \\
\% \text { without a private pension }\end{array}$ & 9.3 & 9.0 & 10.1 & 13.6 & 12.8 & 17.9 & 39.4 \\
\hline$\%$ with occupational pension & 3.6 & 6.7 & 5.8 & 6.6 & 5.7 & 6.1 & $\begin{array}{l}27.4 \\
(1.3)\end{array}$ \\
\hline$\%$ with personal pension & 7.6 & 12.5 & 12.0 & 12.8 & 13.0 & 9.5 & $\begin{array}{l}42.9 \\
(3.7)\end{array}$ \\
\hline$\%$ with both OP and PP & 4.9 & 8.1 & 3.9 & 5.3 & 6.7 & 8.0 & $\begin{array}{l}26.5 \\
(3.0)\end{array}$ \\
\hline All & 5.0 & 7.8 & 6.8 & 7.7 & 7.1 & 7.9 & $\begin{array}{l}30.6 \\
(1.0)\end{array}$ \\
\hline $\begin{array}{c}\text { Individuals not offered an occ. pen. } \\
\% \text { without a private pension }\end{array}$ & 13.9 & 17.8 & 18.4 & 19.3 & 17.9 & 17.5 & $\begin{array}{c}50.4 \\
(2.0)\end{array}$ \\
\hline$\%$ with occupational pension & - & - & - & - & - & - & - \\
\hline$\%$ with personal pension & 13.0 & 17.8 & 15.5 & 16.2 & 18.8 & 15.2 & $\begin{array}{l}49.4 \\
(3.3)\end{array}$ \\
\hline$\%$ with both OP and PP & - & - & - & - & - & - & - \\
\hline All & 13.6 & 17.8 & 17.5 & 18.4 & 18.2 & 16.8 & $\begin{array}{l}50.1 \\
(1.7)\end{array}$ \\
\hline
\end{tabular}

Note: Includes individuals aged 20 to 59 in 1991 who are present in all eight waves only and not selfemployed in any wave. Any move shows the proportion changing employer in any wave by pension status in wave 2. Standard errors for the proportion moving in any wave shown in parenthesis.

Source: British Household Panel Survey, 1992 to 1998 inclusive; authors' calculations.

Of course there may be other correlates with occupational pension scheme take-up that are associated with lower mobility. We know, for example, that occupational pension scheme members tend to be older than personal pension optants, and concentrated in certain industries and occupations (Barrientos, 1998). So we can redo the analysis for more homogeneous groups of workers, or conditioned on other variables. Here we adopt the former strategy, selecting individuals in their 30s, who had the highest take-up rate of personal pensions (Figure 2.2). Table 6.6 therefore examines mobility rates, both year-on-year and cumulative, for this age group, in total and disaggregated by gender. We observe a similar finding to Table 6.5 on average 
and for men: subsequent mobility rates are higher for those who opted to take a personal pension although offered an occupational pension. This difference is significant at $5 \%$ on a one tailed t-test $(10 \%$ on a two-tailed test). However the difference is not significant for women. These results are suggestive, but a multivariate analysis with some explicit structuring of the decision framework is desirable before we can conclude that rates of mobility between occupational pension scheme members and those who declined the occupational pension offer are significantly different.

Table 6.6. Percentage of 30 to 39 year olds who could have joined an occupational pension changing employer, by gender and pension status in previous wave, (employees in wave 2 only)

\begin{tabular}{|c|c|c|c|c|c|c|c|}
\hline \multirow[t]{2}{*}{ Pension status in previous wave } & \multicolumn{6}{|c|}{ Wave } & \multirow{2}{*}{$\begin{array}{l}\text { Any } \\
\text { move }\end{array}$} \\
\hline & 3 & 4 & 5 & 6 & 7 & 8 & \\
\hline $\begin{array}{l}\text { All individuals offered an occ. pen. } \\
\% \text { with occupational pension }\end{array}$ & 3.2 & 8.8 & 5.0 & 5.4 & 5.2 & 6.1 & $\begin{array}{l}29.2 \\
(2.2)\end{array}$ \\
\hline$\%$ with personal pension & 11.1 & 11.9 & 5.2 & 8.5 & 10.5 & 15.9 & $\begin{array}{l}39.7 \\
(6.2)\end{array}$ \\
\hline \multicolumn{8}{|l|}{ Men offered an occ. pen. } \\
\hline$\%$ with occupational pension & 3.5 & 6.8 & 4.8 & 4.5 & 4.3 & 7.8 & $\begin{array}{l}24.8 \\
(2.7)\end{array}$ \\
\hline$\%$ with personal pension & 6.5 & 15.2 & 6.9 & 10.0 & 7.1 & 6.3 & $\begin{array}{l}38.7 \\
(8.9)\end{array}$ \\
\hline \multicolumn{8}{|l|}{ Women offered an occ. pen. } \\
\hline$\%$ with occupational pension & 2.6 & 12.2 & 5.4 & 6.7 & 6.5 & 3.9 & $\begin{array}{l}36.6 \\
(3.9)\end{array}$ \\
\hline$\%$ with personal pension & 15.6 & 8.8 & 3.4 & 7.4 & 12.5 & 21.4 & $\begin{array}{l}40.6 \\
(8.8)\end{array}$ \\
\hline
\end{tabular}

Note: Includes individuals aged 20 to 59 in 1991 who are present in all eight waves only and not selfemployed in any wave. Any move shows the proportion changing employer in any wave by pension status in wave 2. Standard errors for the proportion moving in any wave shown in parenthesis.

Source: British Household Panel Survey, 1992 to 1998 inclusive; authors' calculations.

\section{Conclusion}

This paper has examined a number of consequences of the UK pension reform strategy of the 1980s and 1990s, focussing in particular on the introduction of personal pensions as an additional opting out strategy. We show that, by the end of the 1990s, there was likely to have been some net new household saving through personal pensions, but that the contracting-out structure generates retirement wealth effects that offset the impact on total saving rates. Moreover, the intertemporal public 
budget constraint is affected, with higher current tax rates only partially offset by lower tax rates in the future, when social security payments are lower than they would otherwise have been.

Other, related, policies affected retirement behaviour in the 1980s and 1990s. However it is too early to say whether personal pensions will affect the timing of retirement given the age structure of optants. In any event there are also both wealth and substitution effects that are pertinent in analysing the impact of personal pensions on retirement, and these may go either way.

One facet of personal pensions which has not been explored in the UK literature is their impact on labour mobility. Given selection of workers by employers into occupational pension-covered jobs, and self-selection by workers by type of pension, there is no straightforward answer. However, our prior is that individuals in occupational pensions should exhibit less job mobility than either workers in SERPS or in a personal pension scheme. This is indeed the case. However, we also test a nuance of this, thereby by-passing one of the selection 'routes' described above, by examining whether individuals who were offered occupational pension scheme coverage, but nevertheless chose to buy a personal pension instead, also exhibit higher job mobility. This is also confirmed, although the result is only significant for men. We conclude that personal pensions and greater 'labour market flexibility' are indeed related, but that further analysis is needed if we to test explicit structural models.

\section{Bibliography}

Audit Commission (1997) Retiring Nature: Early Retirement in Local Government, London: Audit Commission.

Agulnik, P., Barr, N., Falkingham, J. and Rake, J. (1999), Partnership in Pensions? Responses to the Pensions Green Paper, CASEpaper no. 24, London: Centre for Analysis of Social Exclusion, London School of Economics.

Banks, J. and Emmerson, C. (2000), 'Public and Private Pension Spending: Principles, Practice and the Need for Reform', Fiscal Studies, vol. 21, no. 1, pp. 1-63.

Banks, J. and Tanner, S. (1999), Household saving in the UK, Report No. 62, London: Institute for Fiscal Studies.

Banks, J., Blundell, R. and Tanner, S. (1998), 'Is There a Retirement-Savings Puzzle?', American Economic Review, vol. 88, no. 4, pp. 769-788.

Barrientos, A. (1998) "Supplementary pension coverage in Britain”, Fiscal Studies, 19, November, 429-446. 
Blake, D. (1995) Pension schemes and pension funds in the United Kingdom, Clarendon Press: Oxford.

Blundell, R., Meghir, C. and Smith, S. (2001), Pension incentives and the pattern of retirement in the $U K$, IFS mimeo.

Blundell, R. and Johnson, P. (1999) 'Pensions and retirement in the United Kingdom', 403435 in Gruber, J. and D. Wise (eds) Social Security and Retirement around the World, Chicago University Press for NBER.

Bodie, Z., Marcus, A.J. and Merton, R. C. (1988) Defined benefit versus defined contribution pension plans: what are the real trade-offs? $139-162$ in Z. Bodie, J. Shoven and D. Wise (eds) Pensions in the US Economy, Chicago University Press for NBER.

Bohn, H. (1997) "Social security reform and financial markets", 193-227 in S. Sass and R. Triest (eds) Social Security Reform: Links to saving, investment and growth, Conference Series No. 41, Boston: Federal Reserve Bank of Boston.

Bos, E., Vu, M. T., Massiah, E. and Bulatao, R. A. (1994), World Population Projections, 1994-95 edition: Estimates and Projections with Related Demographic Statistics, Washington DC: World Bank / Baltimore, Md: Johns Hopkins University Press.

Brugiavini, A. and Disney, R. (1993) "The choice of private pension plans under uncertainty in the UK" Mimeo, Institute for Fiscal Studies.

Budd, A. and Campbell, N. (1998), 'The roles of the Public and Private Sectors in the UK Pension System', in Feldstein, M. (ed), Privatizing Social Security, National Bureau of Economic Research, Chicago: Chicago University Press.

Cabinet Office (2000), Performance and Innovation Unit, Winning the Generation Game, London HMSO.

Chand, S. and Jaeger, A. 1996, Ageing Populations and Public Pension Scheme, Occasional Paper No. 147, Washington DC: International Monetary Fund.

Clark, T. and Taylor, J. (2000), 'Income inequality: A tale of two cycles?', Fiscal Studies, vol. 20, no. 4.

Clark, T. (2001), Recent Pensions Policy and the Pension Credit, Briefing Note No. 17, London: Institute for Fiscal Studies.

Creedy, J., Disney, R. and Whitehouse, E. (1993) 'The earnings-related state pension, indexation and lifetime redistribution in the UK', Review of Income and Wealth, 39, September, 257-278.

Cutler, D., M. Poterba, J.M., Sheiner, L.M. and Summers, L. (1990) "An aging society: opportunity or challenge?” Brookings Papers on Economic Activity, 1, 1-73.

Department of Health and Social Security (1984) Population, Pension Costs and Pensioners' Incomes, London.

Department of Social Security (1998) A New Contract for Welfare: Partnership in Pensions, Cm. 4179, London: HMSO.

Department of Social Security (2000a), The Pensioners' Income Series 1998/99, London: DSS.

Department of Social Security (2000b), The Pension Credit: A Consultation Paper, Cm 4900, London: The Stationary Office.

Department of Social Security (2000c), The Changing Welfare State: Pensioner Incomes, Department of Social Security Paper No. 2, London: DSS.

Dilnot, A., Disney, R. Johnson, P. and Whitehouse, E. (1994) Pensions Policy in Britain: An Economic Analysis, Institute for Fiscal Studies, London. 
Disney, R. (1996), Can we afford to grow older? A perspective on the economics of ageing, Cambridge: MIT Press.

Disney, R. (1997), 'The United Kingdom's pension program'. 157-167 in S. Sass and R. Triest (eds) Social Security Reform: Links to saving, investment and growth, Conference Series No. 41, Boston: Federal Reserve Bank of Boston.

Disney, R. (1999), 'Why have older men stopped working in Britain?' 24-43 in Gregg, P. and Wadsworth, J. (eds) The State of Working Britain, Manchester: Manchester University Press.

Disney, R. (2000) "Crises in OECD public pension programmes: What are the reform alternatives?" Economic Journal Features, 110, February, F1-F23.

Disney, R., Meghir, C. and Whitehouse, E. (1994), 'Retirement behaviour in Britain', Fiscal Studies, vol. 15, no. 1., pp. 24-43.

Disney, R. and Johnson, P. (2001) (eds) Pension systems and retirement incomes across OECD countries, forthcoming, Aldershot: Edward Elgar.

Disney, R. and Smith, S. (2000) 'The abolition of the earnings rule for UK pensioners', mimeo , Institute for Fiscal Studies.

Disney, R. and Whitehouse, E. (1992a) The Personal Pension stampede, London: Institute for Fiscal Studies.

Disney, R. and Whitehouse, E. (1992b) "Personal Pensions and the review of the contractingout terms", Fiscal Studies, 13, February, 38-53.

Disney, R. and Whitehouse, E. (1993a) "Will younger cohorts obtain a worse deal from the UK state pension scheme?" 85-106 in M. Casson and J. Creedy (eds) Industrial Concentration and Economic Inequality, Aldershot: Edward Elgar.

Disney, R. and Whitehouse, E. (1993b) "Contracting out and lifetime redistribution in the UK state pension system", Oxford Bulletin of Economics and Statistics, 55, February, 2542.

Disney, R. and Whitehouse, E. (1996) What are occupational pension plan entitlements worth in Britain? Economica, 63, May, 213-238.

Disney, R., Emmerson, C. and Tanner, S., (1999) Partnership in Pensions: An Assessment, Commentary No. 78, London: Institute for Fiscal Studies.

Disney, R., Emmerson, C. and Wakefield, M. (2001) 'Pension reform and saving in Britain' Oxford Review of Economic Policy, 17, 1 (Spring).

Disney, R., Palacios, R. and Whitehouse, E. (1999) 'Individual choice of pension arrangement as a pension reform strategy', Institute for Fiscal Studies Working Paper W99/18, London.

Emmerson, C. and Johnson, P. (2001) 'Pension provision in the United Kingdom', in Disney, R. and Johnson, P. (2001) (eds) Pension systems and retirement incomes across OECD countries, forthcoming, Aldershot: Edward Elgar.

Emmerson, C. and Tanner, S. (1999), The Government's Proposals for Stakeholder Pensions, Briefing Note no. 1, London: Institute for Fiscal Studies.

Emmerson, C. and Tanner, S. (2000) "A note on the tax treatment of private pensions and Individual Savings Accounts", Fiscal Studies, 21, March, 65-74.

Engen, E.M. and Gale, W.G. (1997) 'Effects of social security reform on private and national saving', 103-142 in S. Sass and R. Triest (eds) Social Security Reform: Links to saving, investment and growth, Conference Series No. 41, Boston: Federal Reserve Bank of Boston. 
Financial Services Authority (2000), Personal Pensions mis-selling: the facts, London: FSA.

Gale, W.G. (1998) "The effects of pensions on household wealth: A re-evaluation of the theory and evidence", Journal of Political Economy, 104, 4, 706-723.

Goodman, A. and Webb, S. (1994), For Richer for Poorer: The Changing Distribution of Income in the United Kingdom, 1961-94, Commentary no. 42, London: Institute for Fiscal Studies.

Government Actuary's Department (1999), National Insurance Fund Long Term Financial Estimates, London: The Stationary Office Limited.

Gustman, A. and Steinmeier, T. (1993) Pension portability and labour mobility: Evidence from the Survey of Income and Program Participation, Journal of Public Economics, 50, 299-323.

Hemming, R. and Kay, J.A. (1982) 'The costs of the state earnings-related pension scheme', Economic Journal, 92, June, 300-319.

Henley, A., Disney, R. and Carruth, A. (1994) Job tenure and asset holdings, Economic Journal, 104, March, 338-349.

HM Treasury (2000a), Pre-Budget Report, November 2000, Cm4917, London: The Stationary Office.

HM Treasury (2000b) Financial Statement and Budget Report, March 2000, London: HM Treasury

HM Treasury (2000c) Tax Ready Reckoner and Tax Reliefs: November 2000, London: HM Treasury.

HM Treasury (2000d) Review of Ill Health Retirement in the Public Sector, London: HM Treasury.

HMSO Inland Revenue Statistics, various issues.

House of Commons (2000) The contributory principle: Firth Report of the Social Security Committee, HC-56, Volume II, Appendix 25, London: HMSO.

Ippolito, R.A. (1997) Pension Plans and Employee Performance, Chicago University Press.

Johnson, P. and Stears, G. (1995), 'Pensioner income inequality', Fiscal Studies, vol. 16, no. 4, pp. 69-93.

Lawson, N. (1992) The View from No. 11: Memoirs of a Tory Radical, Corgi Books: London.

Lazear, E. and Moore, R. (1988) Pensions and turnover, 163-190 in Z. Bodie, J. Shoven and D. Wise (eds) Pensions in the US Economy, Chicago University Press for NBER.

Lazear, E.P. (1979) Why is there mandatory retirement? Journal of Political Economy 87, 6, 1261-1284.

McCormick, B. and Hughes, G. (1984) The influence of pensions on job mobility, Journal of Public Economics, 23, 183-206.

Mealli, F. and Pudney, S. (1996) Occupational pensions and job mobility in Britain: Estimation of a random-effects competing risks model, Journal of Applied Econometrics, 11, 293-320.

Miles, D. (1999) "Modelling the impact of demographic change on the economy", Economic Journal, 109, January, 1-36.

Modigliani, F. (1986) 'Life cycle, individual thrift and the wealth of nations' American Economic Review, 76, June, 297-313. 
Murthi, M., Orszag, J.M. and Orszag, P.R. (1999) Administrative costs under a decentralised approach to individual accounts: lessons from the United Kingdom, Discussion paper, Birkbeck College, London.

National Audit Office (1991) The Elderly: Informational Requirements for Supporting the Elderly and Implications of Personal Pensions for the National Insurance Fund, London: HMSO.

National Audit Office (2000), State Earnings-Related Pension Scheme: The failure to inform the public of reduced rights for widows and widowers, Hc320, London: The Stationary Office.

Office for National Statistics (2000), Living in Britain: Results from the 1998 General Household Survey. London: The Stationary Office Limited.

Peacock, A. (1992) 'The credibility of economic advice to government', Economic Journal, 102, September, 1213-1222.

Roseveare, D., Leibfritz, W., Fore, D., and Wurzel, E., (1996), 'Ageing populations, pension system and government budgets: Simulations for 20 OECD countries', Working Paper No 168, Paris: OECD.

Whitehouse, E. (2000) Administrative charges for funded pension systems: an international comparison and assessment, Social Protection Discussion Paper No. 0016, Washington: World Bank. 